\title{
Development characteristics and controlling factor analysis of the Neogene Minghuazhen Formation shallow water delta in Huanghekou area, Bohai offshore basin
}

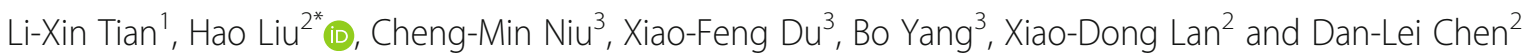

\begin{abstract}
Based on a combination of high resolution 3-D seismic, drilling and well logging and core data, this study focuses on describing the depositional features of the Neogene Minghuazhen Formation shallow water delta in Huanghekou area (HHKA), Bohai offshore basin and discussing the evolution and controlling factors of shallow water delta sandbody. An obvious meandering fluvial delta system developed in sequence 1 (SQ1) of the Neogene in HHKA with thinner sandbody of distributary channels and poor development of mouth bar. The sequence texture obviously influences the vertical development and stacking pattern of sandbodies and controls the distribution of sandbodies in plain view as well. In shallow water lacustrine basins, relative topographic height difference leads to change of distribution of accommodation space, and sandbodies of distributary channels usually develop well in local low-lying areas where accommodation space increases. The delta is dominated by distributary channel sandbodies during the early period of base level rising. Sandbodies contact with each other in a lateral stacking pattern and are characterized by a fan shape in plain view. Distributary channels gradually narrow and tend to shift during the mid- late-period of base level rising, while the sandbodies are characterized by a net shape in plain view. During the period of base level slow falling, the multistory/multilateral channel sandbodies dominated the inner front of shallow-water delta and the delta sand dispersal distributes as a lobe shape.
\end{abstract}

Keywords: The Neogene Minghuazhen Formation, Huanghekou area, Bohai offshore basin, Shallow water delta, Micro-palaeogeomorphology, Base level, Sandbody stacking pattern

\section{Introduction}

The Neogene of the Bohai offshore basin, including Guantao and Minghuazhen Formations, is a typical lacustrine basin shrinking period deposition. Previous researchers considered that widely distributed, unified large-scale shallow water lake and shallow water delta deposited in the Neogene based on analysis of geologic and geophysical data in recent years (Xu et al. 2002; Dai et al.2007; Zhu et al. 2008; Lai et al. 2009; Liu 2014; Li et al. 2014; Liu et al. 2016). Latest resource evaluation

\footnotetext{
* Correspondence: Ihcugb@163.com

${ }^{2}$ School of Ocean Sciences, China University of Geosciences (Beijing), Beijing

100083, People's Republic of China

Full list of author information is available at the end of the article
}

indicates (Zhu et al. 2008) that the total reserves of the Bohai offshore basin is about 3.5 billion cubic, among which about 2.2 billion cubic is from the Neogene; 1.5 billion cubic is found in shallow water delta accounting for $68 \%$ of the Neogene and $43 \%$ of the total reserves respectively which makes a significant contribution to the annual 3000, $0000 \mathrm{t}$ production of the Bohai Oilfield. It is evident that hydrocarbon accumulations exploration of shallow strata of the Neogene, especially relevant with shallow water delta sandbodies plays an important role.

The concept of shallow water delta (Fisk 1961) has been continuously applied and summarized in practice 
and researches (e.g. Donaldon, 1974; Coleman 1988; Postma 1990; Nichols 2005; Nichols and Fisher 2007; Fisher et al. 2007; Alonso-Zarza et al. 2011; North and Davidson 2012). Wide attention has been paid to sedimentology and petroleum geology domains as a research hotspot due to its unique sedimentary facies types and petroleum implication. Shallow water delta generally refers to river-controlled delta with distributary channel (aquatic and subaqueous) as skeletal sandbody which forms in platform and epicontinental sea (lake) with shallow water and relatively stable tectonics or depressional basins with gentle topography and entirely slowly subsiding setting (Fisk 1961; Donaldon 1974; Coleman 1988; Postma 1990; Fisher et al. 2007; Alonso-Zarza et al. 2011). Many detailed researches have been conducted regarding the developing characteristics, formation mechanisms etc. due to their significant difference with the traditional Gilbert-type delta (Gilbert 1885; Zhu et al. 2017). These researches indicate that shallow water delta is characterized by distributary channel sandbody as its skeletal sandbody, thinner even no mouth bar sandbody, very wide delta front belt and sandbody in stripe-direction (e.g. Lemons and Chan 1999; Plint 2000; Hoy and Ridgway 2003; Ganil and Bhattacharya 2007; Keumsuk et al. 2007; Dai et al. 2007; Zhu et al. 2008; Zou et al. 2010; Zhu et al. 2017). Combining geophysical, drilling and well logging, core data, many researchers have identified the sedimentary features, depositional model, sedimentary dynamics and controlling factors of hydrocarbon accumulations of shallow water delta in Songliao Basin, Ordos Basin, Sichuan Basin, Bohai Bay Basin in recent years (Lü et al. 1999; Han et al. 2000; Dai et al. 2007; Zhu et al. 2008; Lai et al. 2009; Liu et al. 2009; Zou et al. 2010; Zhang et al. 2010; Li et al. 2014; Liu, 2014; Liu et al. 2016, 2018; Zhu et al. 2017).

Based on a combination of high resolution 3-D seismic, drilling and well logging and core data, this study focuses on: (1) describing the depositional features of the Neogene Minghuazhen Formation shallow water delta in Huanghekou area (HHKA) and identifying planar distribution characters of sedimentary facies within different sequences; (2) detailed interpretation of 3-D seismic data and sandbody prediction of key areas; and (3) discussion of developing evolution and control factors of shallow water delta sandbody in key areas, deciphering the influence of sequence texture, base level and palaeogeomorphology on sandbody development.

\section{Regional geologic background}

The HHKA is located in the southeastern Bohai offshore basin, between the South Bohai low uplift and the North Laizhouwan low uplift, with an area of $3300 \mathrm{~km}^{2}$ (Gong et al. 2000; Tian et al. 2009; Zhou et al. 2010; Liu et al. 2015; Liu et al. 2017; Feng et al. 2016). Rifting occurred in the Paleogene, and the sag was dominated by stable post-rift subsidence. Since the Neogene tectonic movement period, in a nearly south-north stretching setting, the main sliding fracture in north-north-east direction and two sets of fracture systems in a nearly east-west direction were developed in the HHKA (Glider et al, 1999; Schellart \& Lister, 2005; Qi et al. 2008) (Fig. 1).

The Cenozoic Bohai offshore basin, characterized by a rift and depression tectonic units, experienced a tectonic evolution of multi-stage rift, multi-stage stacking, multi-origin composition, and a complete rift cycle basically finished after the Paleogene rift subsidence stage and the Neogene-Quaternary post-rift thermal subsidence stage (Brendan et al. 2000; Hsiao et al, 2010). In an ascending order, the Pre-Cenozoic (the Jurassic and the Cretaceous), the Paleogene Kongdian Formation, Shahejie Formation and Dongying Formation, the Neogene Guantao Formation, Minghuazhen Formation and the Quaternary Pingyuan Formation developed in the HHKA. The Paleogene was dominated by lacustrine deposits which unconformably contacted with the overlying Neogene.

The lower member of Minghuazhen Formation is grey green, brownish red mudstone interbedded with grey green, light grey silt fine sandstone with biological association of Magnastriatites - Fupingopollenites - Liquidambarpollenites. The upper member is dominated by grey green, brownish red mudstone interbedded with grey white medium- fine-sandstone. Two third-order sequences and four systems tracts (Fig. 2) were divided through a comprehensive analysis of seismic, drilling well, well logging and core data within the lower member of Miocene Minghuazhen Formation (Liu 2014; Liu et al. 2016, 2018). This study focuses on sequences divided by Liu (2014), Liu et al. (2018) taking SQ1 as the target to analyze developing characters and controlling factors of the shallow water delta.

\section{Data and methods}

High quality subaqueous data involved in this study are from Tianjin Branch, CNOOC, including 3-D seismic, core, drilling well and well logging data. 3-D seismic data include five 3-D surveys in total about $10,000 \mathrm{~km}^{2}$. 3 -D seismic data have a vertical sampling rate of $2 \mathrm{~ms}$ and were processed to zero phase. Seismic data were displayed as reversed polarity. The 3-D seismic data of the Miocene have a dominant frequency of $25-50 \mathrm{~Hz}$ and an average frequency of about $35 \mathrm{~Hz}$ in the studied interval, with a vertical resolution of about $10-20 \mathrm{~m}$. Totally 80 drilling wells were used in this study from the Neogene of HHKA with cuttings log and logging data (gamma, acoustic, density, spontaneous potential etc.). 11 drilling wells have core data with an overall length of about $1200 \mathrm{~m}$. Integration of these drilling well data and seismic data can establish the regional stratigraphic 

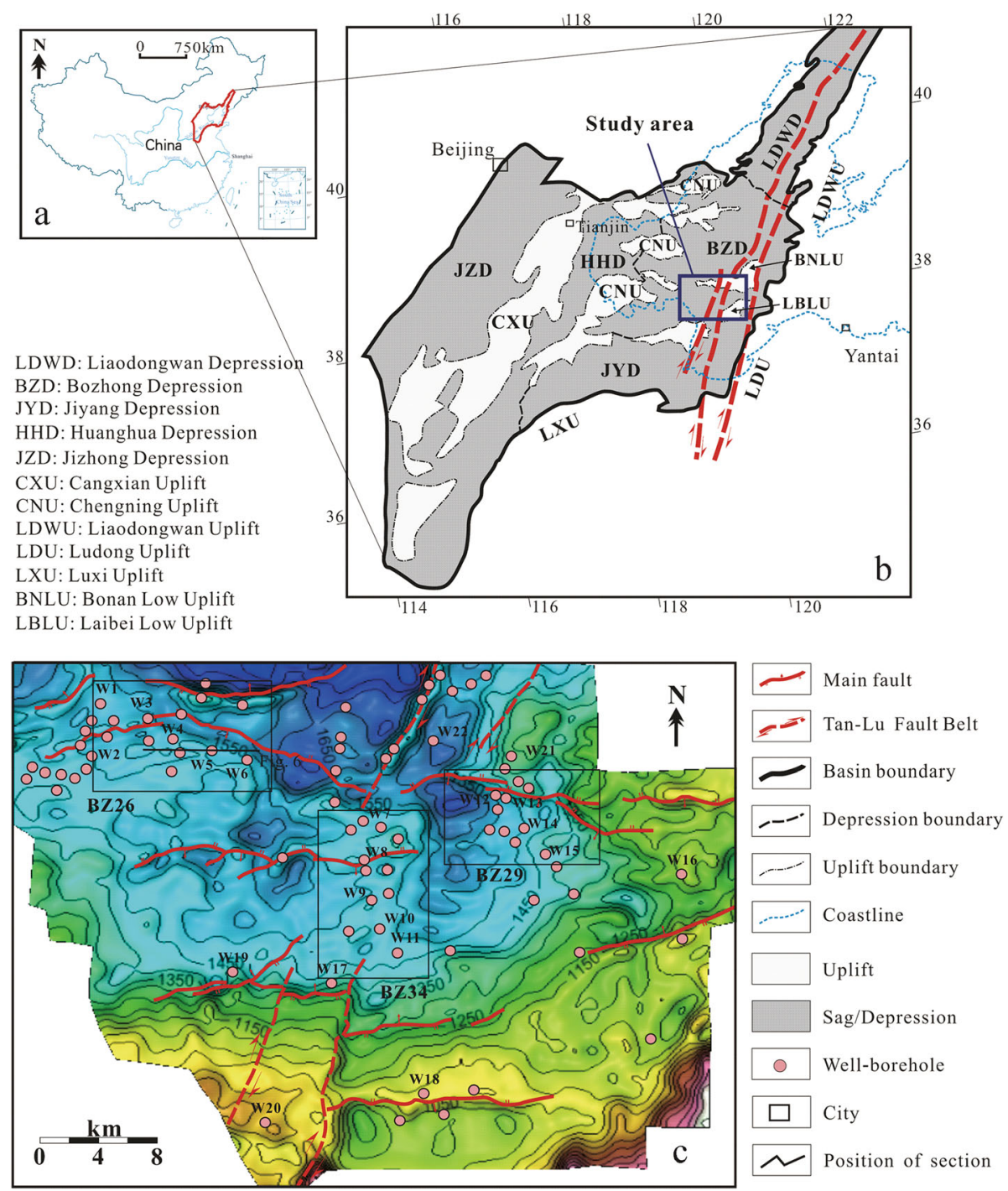

Fig. 1 a Location of the Bohai Bay Basin marked in red color (Inset map of China is modified after State Bureau of Surveying and Mapping, GS(2016)1591), b Map showing structural units of the bottom surface of the Paleogene in entire Bohai Bay Basin, c Thickness map (time domain) of the Neogene of the HHKA, a macro-reflection of topography of the Neogene depressional lacustrine basin in the HHKA

framework through calibration of synthetic seismogram and seismic interpretation of the study area can be conducted. In addition, regional sedimentary facies analysis, quantitative study, compilation of sedimentary system and palaeogeomorphic maps are based on these results.

Identification and subdivision of high frequency sequences selects key areas (BZ34, BZ26 and BZ29) and sequence SQ1. Strata are divided into transgressive, regressive and aggressive parasequence sets (PSS) according to different stacking patterns (Vail et al. 1977; Van Wagoner et al. 1988; Vail et al. 1991). Ten PSS are divided in BZ34, BZ26 and BZ29 areas, in which 4 PSS developed in transgressive systems tracts (TST) and 6 PSS developed in highstand systems tracts (HST). Therefore the high frequency stratigraphic framework is established (Fig. 3). PSS type is obviously related with sequence systems tract. Transgressive PSS mainly develops in early period of TST and late period of HST, regressive PSS mainly develops in early or late periods of TST and aggressive PSS develops in early period of HST.

Sandbody deciphering strictly follows seismic attributes interpretation technology based on geologic-seismic model within the high resolution sequence framework (Liu et al. 2018). Liu et al. (2018) proposed that a close relationship between the root mean square amplitude and lithology associations occurred within the PSS, among which high amplitude usually corresponding to thicker sandstone, while lower amplitude representing abundance of mudstone. Therefore, based on 3-D seismic data detailed interpretation of sequence boundary of PSS, 


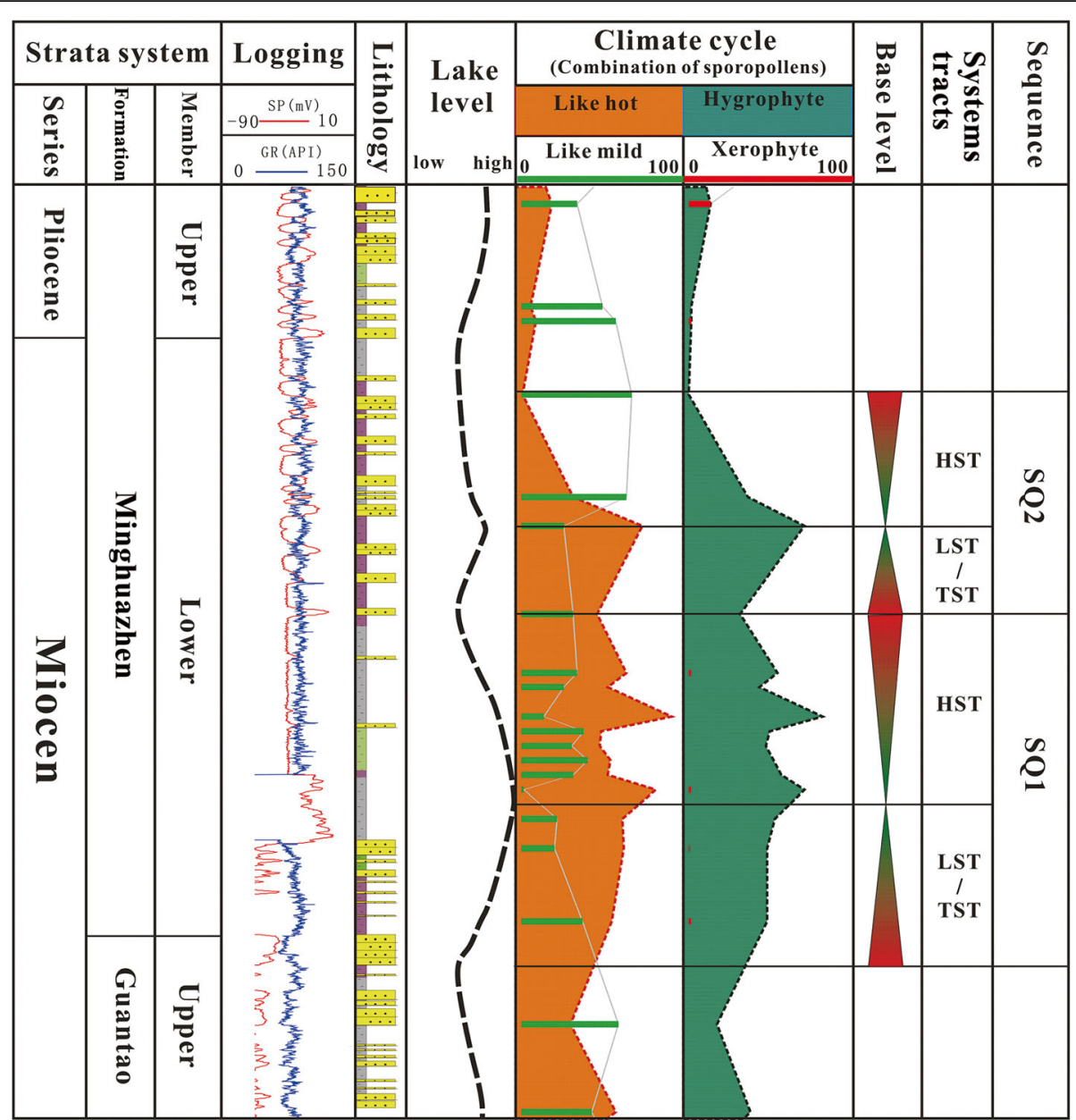

Fig. 2 Sequence stratigraphic division of the Minghuazhen Formation of Neogene in HHKA. Note the statistic analysis of climate cycle is mainly through sporopollen association amount which is similar as the analysis result of Dai et al., 2009 and Liu et al. 2016. SQ-Sequence, LST-Lowstand systems tract, TST-Transgressive systems tract, HST-Highstand systems tract

stratal slicing and seismic sedimentological analysis will be used to predict the spatial distribution of sandbodies.

\subsection{Sedimentary characteristics of shallow water deltas}

The Neogene Minghuazhen Formation of the HHKA mainly developed delta and lacustrine facies. Delta was dominated by meandering fluvial delta which is widely acknowledged as "shallow water delta" (Dai et al. 2007; Zhu et al. 2008; Lai et al. 2009; Li et al. 2014; Liu 2014; Liu et al. 2016, 2018) due to the shallow water depth during deposition.

\subsection{Drilling-logging characteristics}

Shallow water deltas form when rivers flow into shallow water area and discharge there. Compared to the normal delta, shallow water deltas are characterized by specific sedimentary characteristics including well developing of subaqueous distributary channel sandbody, rare mouth bar, wide distribution of sheet sand and delta-shaped distribution of sandbody etc. due to its shallow water depth, gentle subaqueous topography and non-obvious morphology slope, dominant fluvial transgression and weak reconstruction of lake wave (Fisk 1961; Donaldon 1974; Coleman 1988; Postma 1990; Zhu et al. 2008; Li et al. 2014; Liu et al. 2016; Zhu et al. 2017). However, exactly as normal deltas, shallow water deltas are subdivided into subfacies of subaerial plain, subaqueous plain, delta front and prodelta. Microfacies of distributary channel, natural levee, fan and intra distributary channel depression develop in subaerial plain and subaqueous plain of the shallow water delta; subaqueous distributary channel, mouth bar, sheet sandbody formed by sheeting of subaqueous distributary channel, and mud flat (river bay) develop in shallow water delta front; shallow water prodelta is dominated by prodelta mudstone (shallow lacustrine mudstone). Delta is respectively described as inner delta front and outer delta front in this paper. 

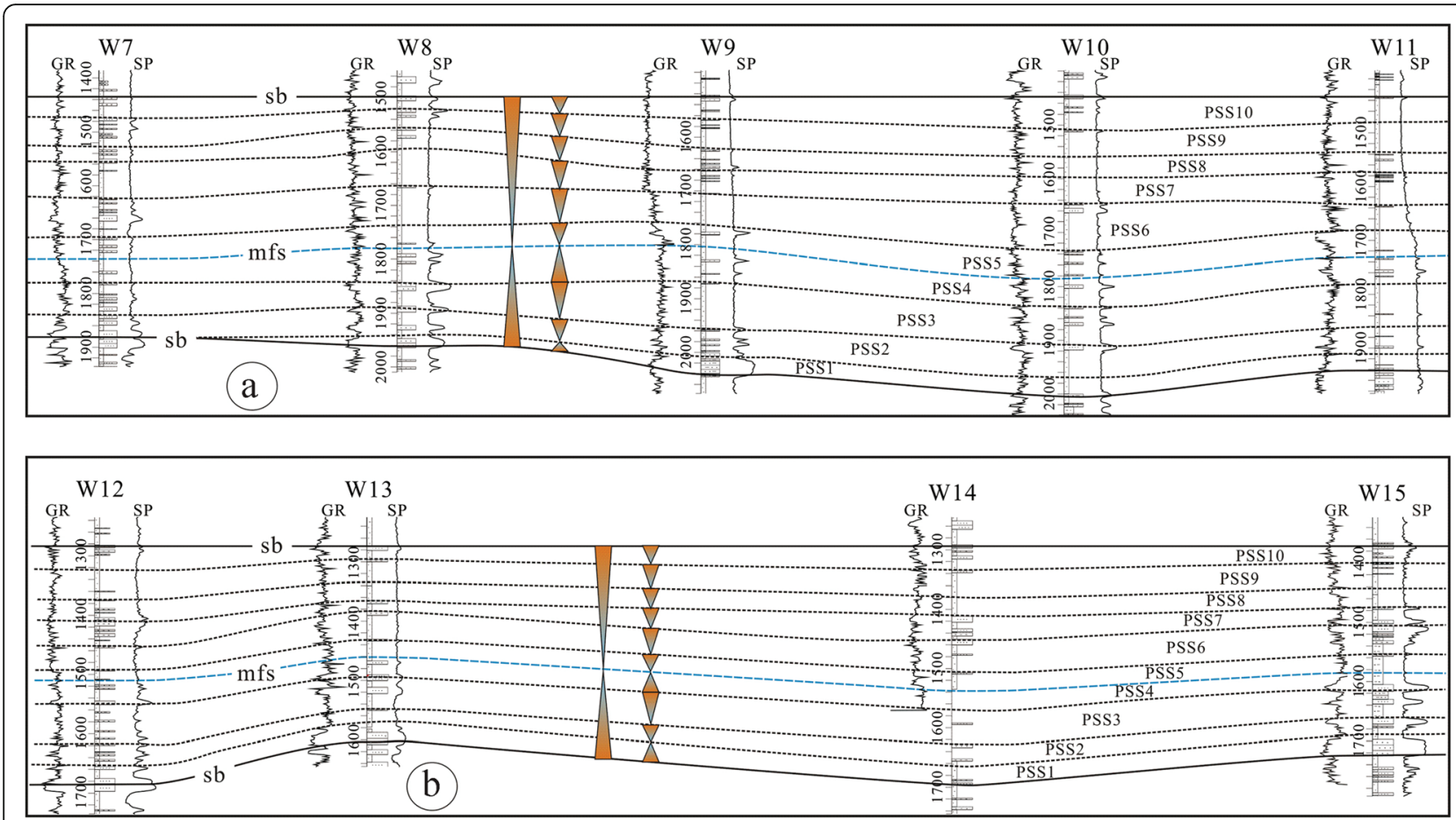

Fig. 3 Section of classification and comparison of parasequence sets in SQ1 in the lower member of Minghuazhen Formation in HHKA. Logging curves in the figure are mainly gamma (GR) and spontaneous potential (SP) curves. Locations of drilling wells are shown in Fig. 1. a-BZ34 area; b-BZ29 area; PSS-Parasequence set; sb-Sequence boundary; mfs-maximum flooding surface

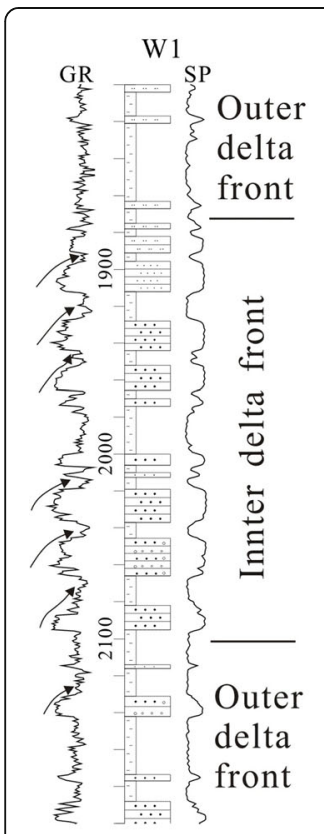

a

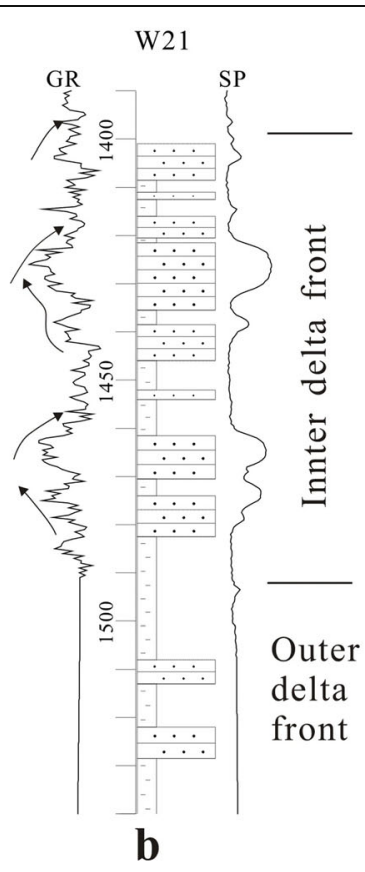

Medium-finesandstone and siltstone
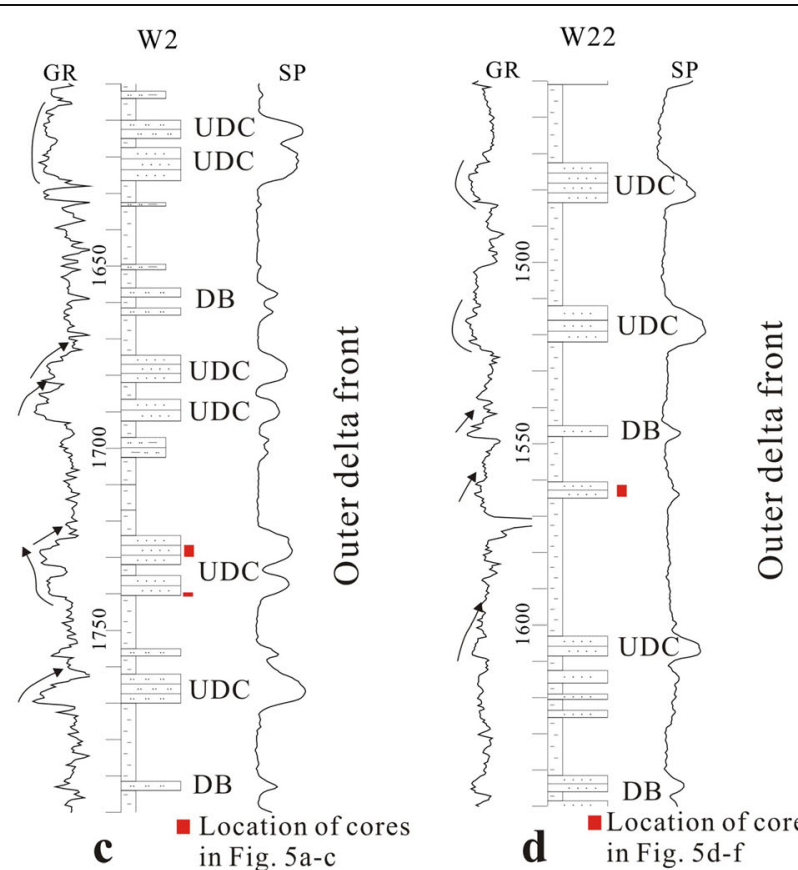

d in Fig. $5 \mathrm{~d}-\mathrm{f}$

\section{$\because \cdots$ Coarse sand and $\because \therefore$ conglomerate}

Silty mudstone and mudstone

Fig. 4 Lithofacies characteristics and vertical successions of shallow water delta in the HHKA. Wireline logs are spontaneous potential (SP) and gamma (GR). UDC- Underwater distributary channel; DB- Distal bar 
Inner delta front subfacies can be divided into subaqueous main distributary channel and mouth bar microfacies. Subaqueous main channel is lithologically dominated by conglomerate-bearing coarse sandstone, coarse sandstone, medium sandstone and fine sandstone characterized by high resistivity, low gamma, bell- or funnel-shaped positive high abnormal spontaneous potential (Fig. 4a-b). Mouth bar deposition is not obvious which agrees well with previous researches (Dai et al. 2007; Zhu et al. 2008; Lai et al. 2009; Li et al. 2014; Liu 2014; Liu et al. 2016).

Outer delta front subfacies can be divided into subaqueous distal distributary channel and distal sand bar microfacies. Meandering fluvial delta subaqueous distal channel is lithologically dominated by medium sandstone and fine sandstone (Fig. 5a-c). Logging curve is characterized by high resistivity, low gamma, bell-, funnel- and box-shaped positive high abnormal spontaneous potential (Fig. 4c).
Distal sandbar is lithologically dominated by fine sandstone, siltstone, muddy siltstone, silty mudstone and mudstone with unclear cross bedding and blocking bedding structure (Fig. 5d-f). Logging curve is characterized by high resistivity, low gamma, bell-, funnel- and box-shaped high positive abnormal spontaneous potential (Fig. 4d).

\subsection{Seismic reflection features}

Shallow water delta, lacking typical progradation reflection texture, is obviously different from normal delta on seismic reflections. It is characterized by medium-high amplitude, medium continuity, parallel-subparallel or small-scale hummocky or lenticular seismic reflections. Small-scale hummocky or lenticular seismic reflection possibly reflects distributary channel deposition of shallow water delta (Fig. 6). Lacking of progradation seismic reflection indicates the lacking of mouth bar deposition of a delta. Weak

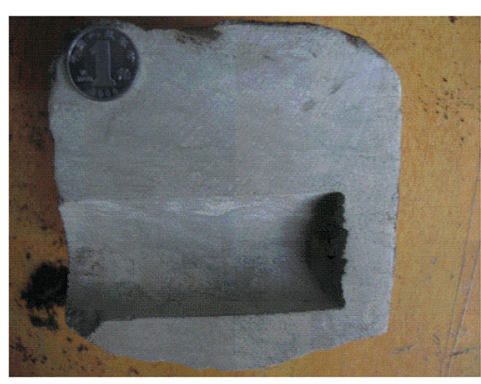

a

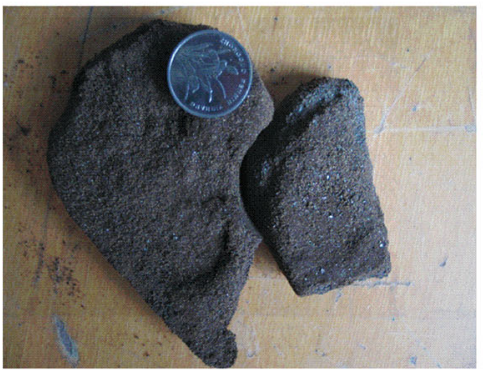

c

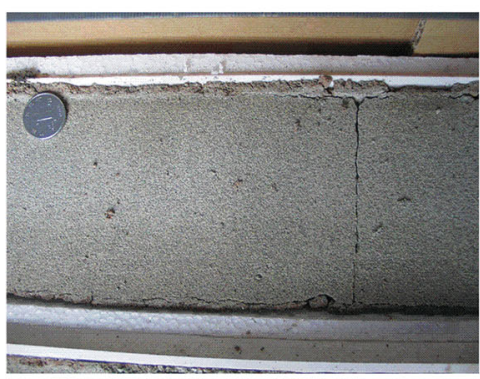

e

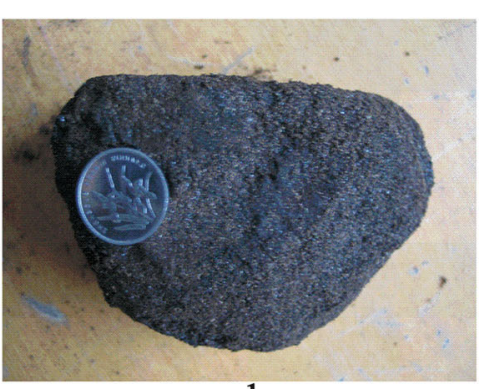

b

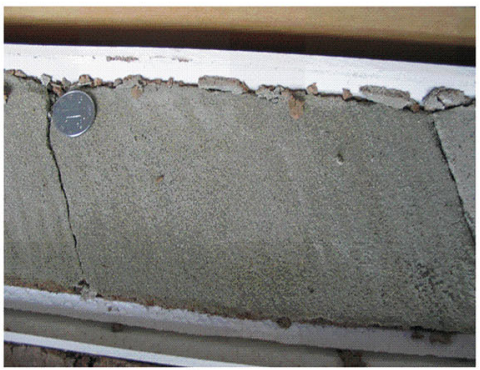

d

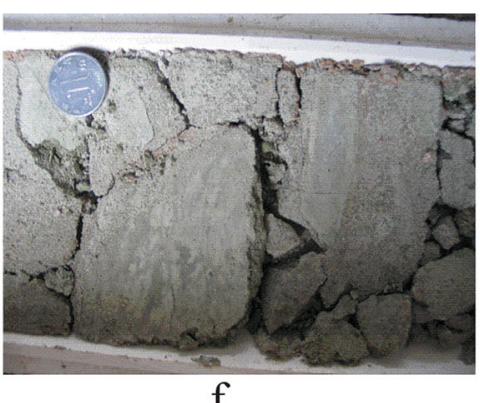

f

Fig. 5 Photographs of representative various types of lithofacies. See Fig. 4 for location of cores. a grayish green siltstone with unclear crossbedding; b brown medium sandstone; c oil-bearing, brown fine sandstone; $\mathbf{d}$ grayish white fine sandstone with low-angle cross bedding; e grayish white fine sandstone; and $\mathrm{f}$ grayish white fine sandstone containing mud gravels with the maximum size of 7 mm 


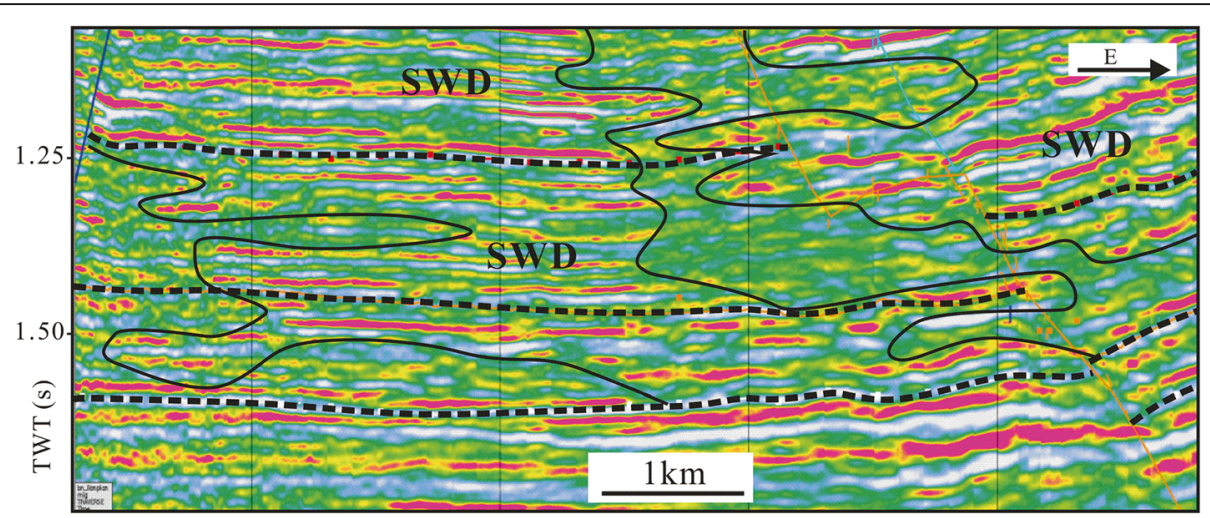

Fig. 6 Seismic reflection characteristics of the shallow water delta of the lower member of Minghuazhen Formation in HHKA. Locations of seismic profiles are shown in Fig. 1. SWD-shallow water delta

hummocky seismic refection with medium-low, medium amplitude, increasing continuity is possibly interpreted as sheet sands of outer delta front or prodelta mudstone deposit. Stratal slicing of root mean square amplitude indicated (Fig. 7) the apparent distribution within the inner delta facies belts, approximately dividing into 1) distributary channel system, dominated by subaqueous distributary channel, main channel obviously controlling sandbody development usually with multi-period development; 2) distributary channel-distal sandbar association, decreasing amplitude, obviously thinning sandbody, non-dominant distributary channel associating with distal sandbar; 3) distal bar-distributary channel association, continuously decreasing amplitude, thinning sandbody, dominant distal sandbar, secondary development of distributary channel; and 4) distal sandbar-beach association, thinner sandbody, dominated by distal sandbar with development of shallow lake sand beach.

\subsection{Sand/strata ratio and planar characteristic of the depositional system}

Based on compilation of sequence and strata thickness, over 80 drilling wells' logging and well $\log$ data of the HHKA area were calculated, sandbody percentage of each individual systems tract was calculated, contour maps of sandbody percentage of SQ1 transgressive and highstand systems tracts were drawn to investigate the distribution character of each systems tract. These results provided a foundation for analyzing the general regularity of depositional systems.

The average sand content of TST of SQ1 is about 27\%, obviously less than that of the lower part of the Guantao Formation. Relatively sand-rich belts with sand content larger than $40 \%$ were located in northwest, northeast, southwest and east of the study area developing in flower shape. Relatively sand-poor belts with sand content ranging in $20 \%-40 \%$ were widely distributed.
Sand-poor belts with sand content less than 20\% were located in central sink and northern side of the west part and the sand-poor belt in central sink was distributed in NNE direction (Fig. 8a). Provenance respectively from northwest, southwest, northeast and east occurred during the lake expanding depositional period among which northwest and northeast provenance dominated relatively. Depositional systems of this period include meandering fluvial, shallow water delta and shallow lake. Meandering fluvial depositional system developed in east and south parts, dominated by flood plain subfacies and meandering fluvial channel developed in the north side of the east and northeast part (Fig. 8b). Meandering fluvial delta, identified as inner front and outer front subfacies, developed in northwest, southwest and shore-shallow lake area neighbouring the north side of east part and meandering fluvial channel of northeast. Wide shore-shallow lake area was dominated by shore-shallow mudflats and sand-mud mixed beach.

The average sand content of HST of SQ1 is about $22 \%$, and relatively sand-rich belt with sand content larger than $40 \%$ is mainly located in southwest and northeast and secondly in the small lobe body of northwest and southeast. Thin sand belt with sand content of $20 \%-40 \%$ is distributed widely. Sand-poor belt with sand content less than $20 \%$ is distributed in most of the central sag area. Obviously the lake area in HST expanded more than in TST, provenance supply reduced which was dominated by southwest and northeast directions and southeast and northwest as auxiliary (Fig. 9a). During the depositional period of HST, shore-shallow lake area in southwest shrank and that in the east expanded. Meandering fluvial depositional system dominated by flood plain subfacies developed in south and east of the study area and channel subfacies developed in southwest, south by east and east by south areas (Fig. 9b). Meandering fluvial delta system developed in northwest, 


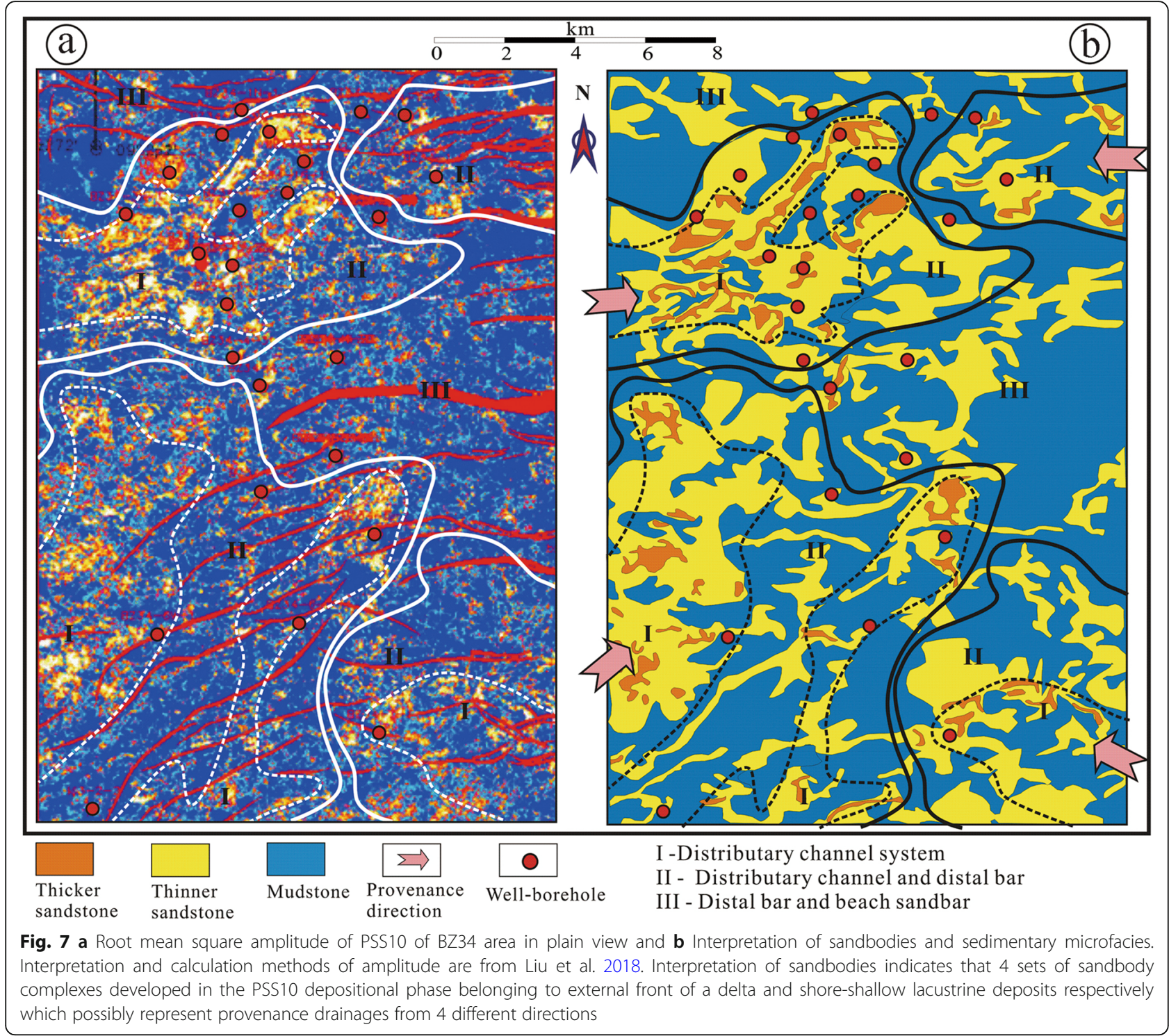

southwest, northeast and southeast of shore-shallow lake area and meandering fluvial deltas in southwest and northeast are with a larger scale. Inner front and outer front subfacies can be identified in meandering fluvial delta depositional system. Shore-shallow lake subfacies is dominated by mudflats and mixed flats.

\section{Discussion: shallow water sand dispersal system and controlling factor analysis}

In recent years, some studies involve in sequence stratigraphic analysis of shallow water depositional systems (e.g. Ghinassi et al. 2009; Hampson et al. 1997; Plint et al. 2001; Nichols 2005; Darmadi et al. 2007; Allen and Fielding 2007; Nichols and Fisher 2007; Fisher et al. 2007; Alonso-Zarza et al. 2011; North and Davidson 2012) which mostly relates with marine coastal plain or shallow marine environments and divides systems tract according to base level and accommodation space change and then furthermore predicts and describes the internal strata stacking pattern of a sequence. The Neogene Bohai offshore basin was characterized by stable tectonics, slow subsidence, wide lake area, no separation of the interior, gentle topography, small slope etc. (cf. Zhu et al. 2008; Liu et al. 2018) which developed meandering fluvial dominated by channel and shallow water delta dominated by distributary channel. Changes of sandbody characteristics are directly controlled by sequence texture, microgeomorphology, base level and sedimentary facies type. Investigating how it is that one or multiple genetic mechanism controls the temperal-spatial distribution of sandbody and establishing shallow water 

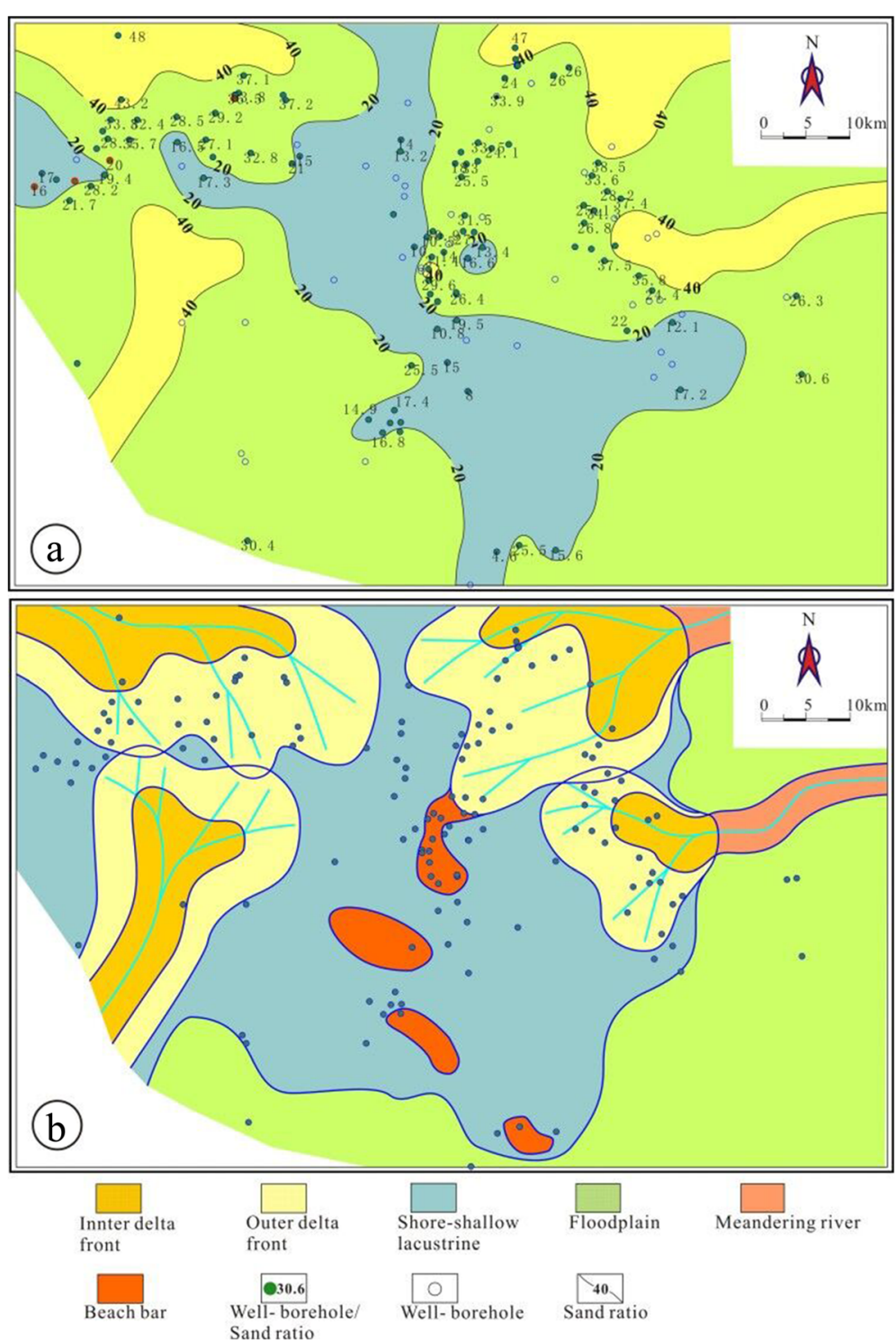

Fig. 8 Sand/strata ratio (a) and sedimentary facies (b) distribution characters of the transgressive systems tract of SQ1 in plain view

delta sandbody dispersal pattern play a significant role in petroleum exploration in shallow intervals.

\subsection{Sequence texture controlling vertical inhomogeneity of sandbodies}

Sequence texture obviously influences sandbody distribution during change of base level cycle which mainly reflects as vertical development degree, stacking pattern and planar association relationship of sandbodies.

\subsubsection{Sequence texture controlling vertical development degree of sandbodies}

Statistic analyses of BZ26, BZ34 and BZ29 areas indicate that the maximum value of average sandbody thickness mainly occurs in the early period of TST, secondly in the late period of HST and the minimum value mainly occurs in the late period of TST and early period of HST (Fig. 10).

Maximum thickness tendency of sandbody indicates that the early TST usually develops sandbody with the maximum thickness, the late period of TST and early period of HST usually develop relatively thinner sandbody, whereas late period of HST develops sandbody with thickness between the above two (Fig. 11).

Similar characteristic was acquired through sand-bearing ratio statistic analysis of each PSS. Therefore, following conclusions are acquired based on the maximum, average sandbody thickness and sand-bearing ratio distribution maps. 


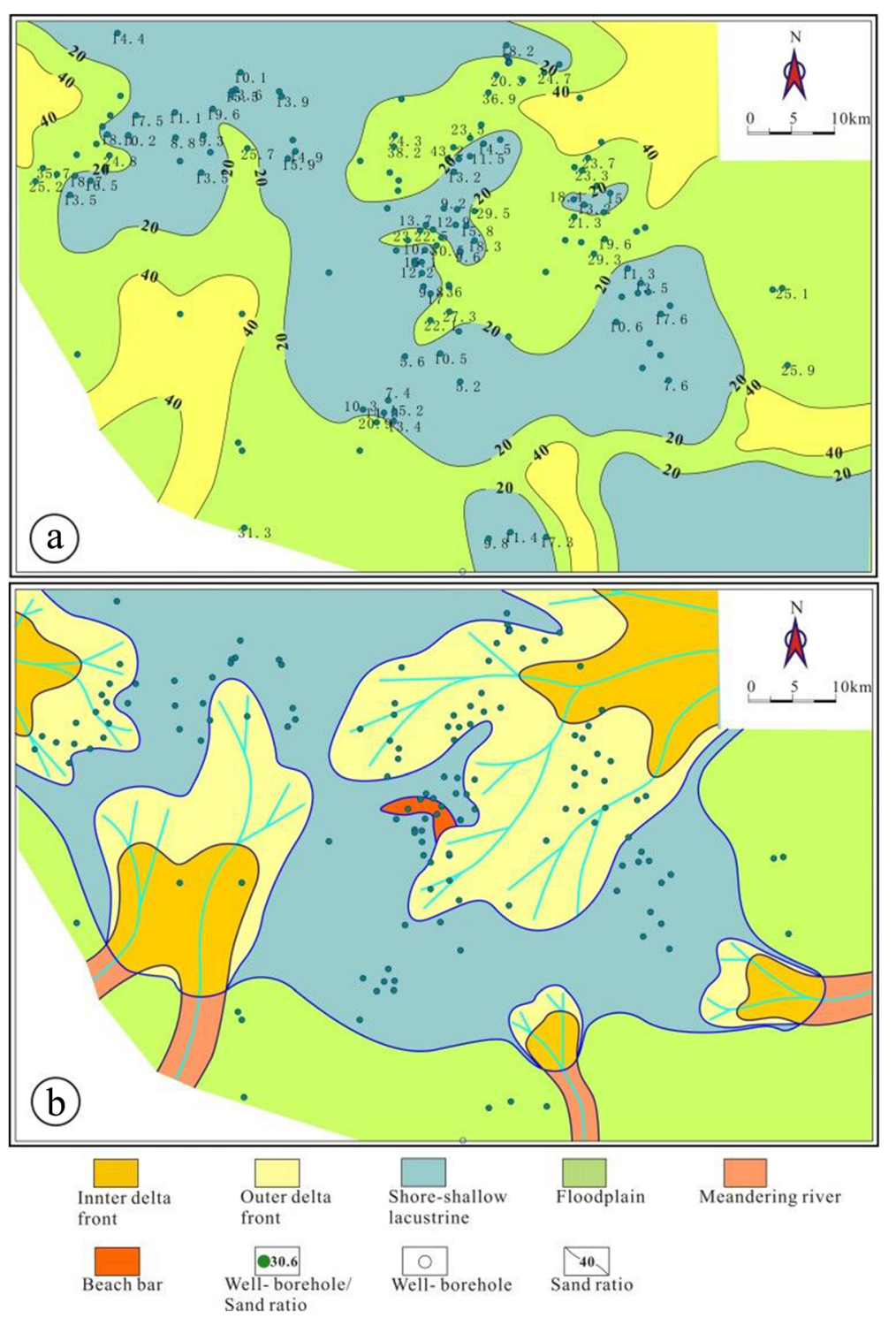

Fig. 9 Sand/strata ratio (a) and sedimentary facies (b) distribution characters of the highstand systems tract of SQ1 in plain view

1) Shallow water delta sandbody develops best during the early period of TST, HST secondly, the late period of TST and early period of HST as the poorest.

2) Difference of depositional locations results in differences in sequence texture and vertical distribution of sandbody. BZ26 area is located in western Huanghekou Depression, relatively closer to the provenance area. Its average and maximum sandbody thickness and sand-bearing ratio show an obvious "high-low-high" character corresponding to TST-early HST-late HST respectively.

3) The development of sandbodies is controlled by the developing pattern of PSS in different systems tracts within a sequence framework. The early period of TST is the depositional phase when sandbody develops best during the entire base level falling process although regressive PSS developed in the early period; the late period of TST is characterized by regressive PSS and sandbodies did not develop widely; the HST is dominated by transgressive PSS and sandbody obviously developed better than that in the TST, whereas the late phase of the HST is obviously better than the early phase in sandbody development.

\subsubsection{Sequence texture controlling the vertical stacking pattern of sandbodies}

The above parts analyzed an obvious difference of sandbody development in different systems tracts and PSS. The 

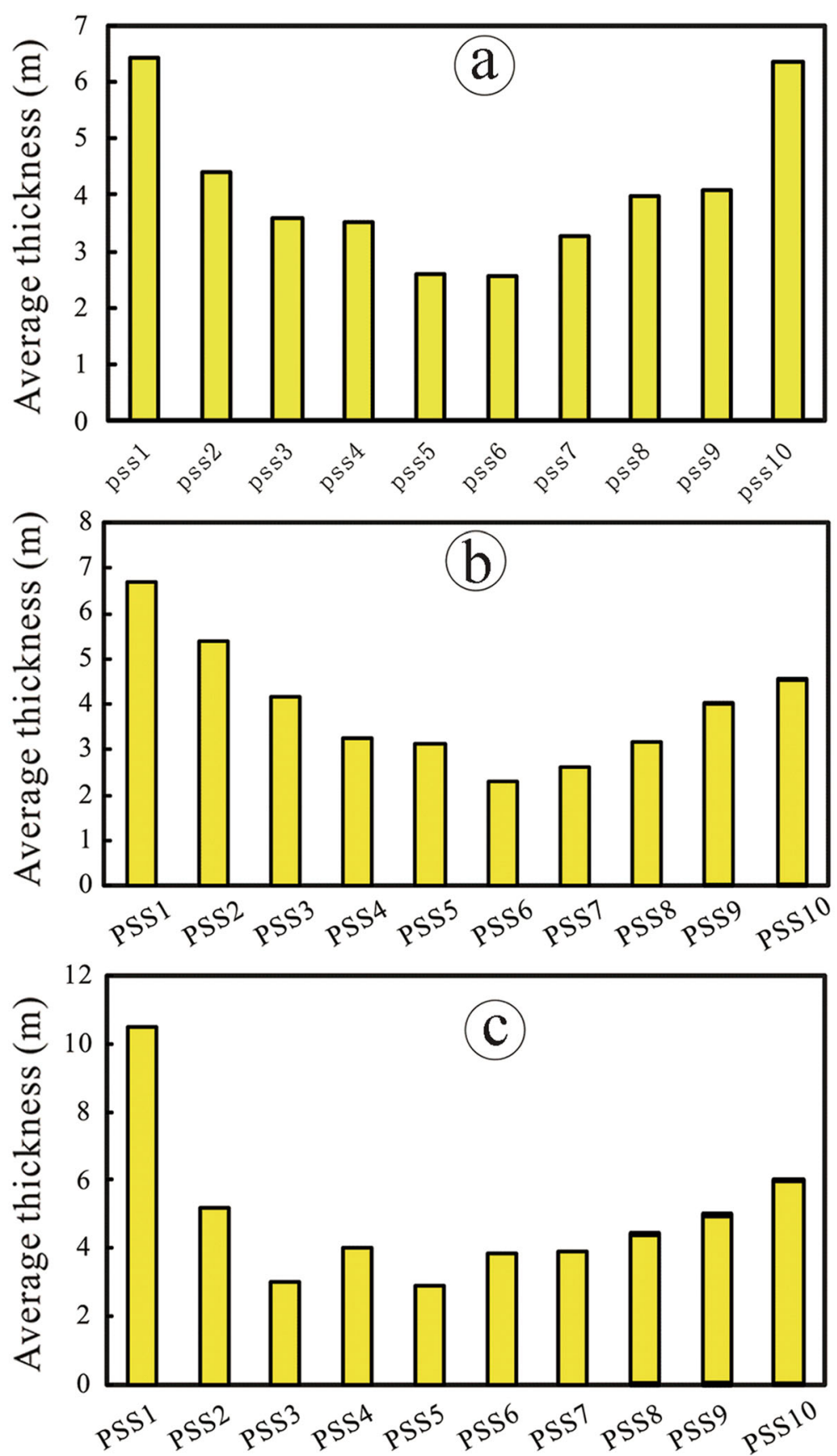

Fig. 10 Distribution of the average thickness of sandstones in individual parasequence sets of SQ1 in HHKA. a-BZ26 area, b-BZ34 area, c-BZ29 area

stacking pattern or texture of sandbody is significantly different in different systems tracts (Liu et al. 2016, 2018).

In the early phase of TST, sandbodies contact with each other in a lateral stacking pattern as piecing together. It is reflected by moderate- to high-amplitude, worm-wave shape seismic reflection. In the late phase of TST, sandbodies are mostly isolated tabular shape with obviously less connections. The seismic reflections are characterized by moderate- to low-continuity, moderate- to high-amplitude with wave-shape reflection configuration. In the late phase of TST - the early phase of the HST, isolated lenticular sandbodies of subaqueous distributary channel developed. The seismic reflections are characterized by moundy configuration with low continuity and low amplitude. Sandbodies developed relatively widely in late phase of the HST. Sandbodies contact with each other in a 

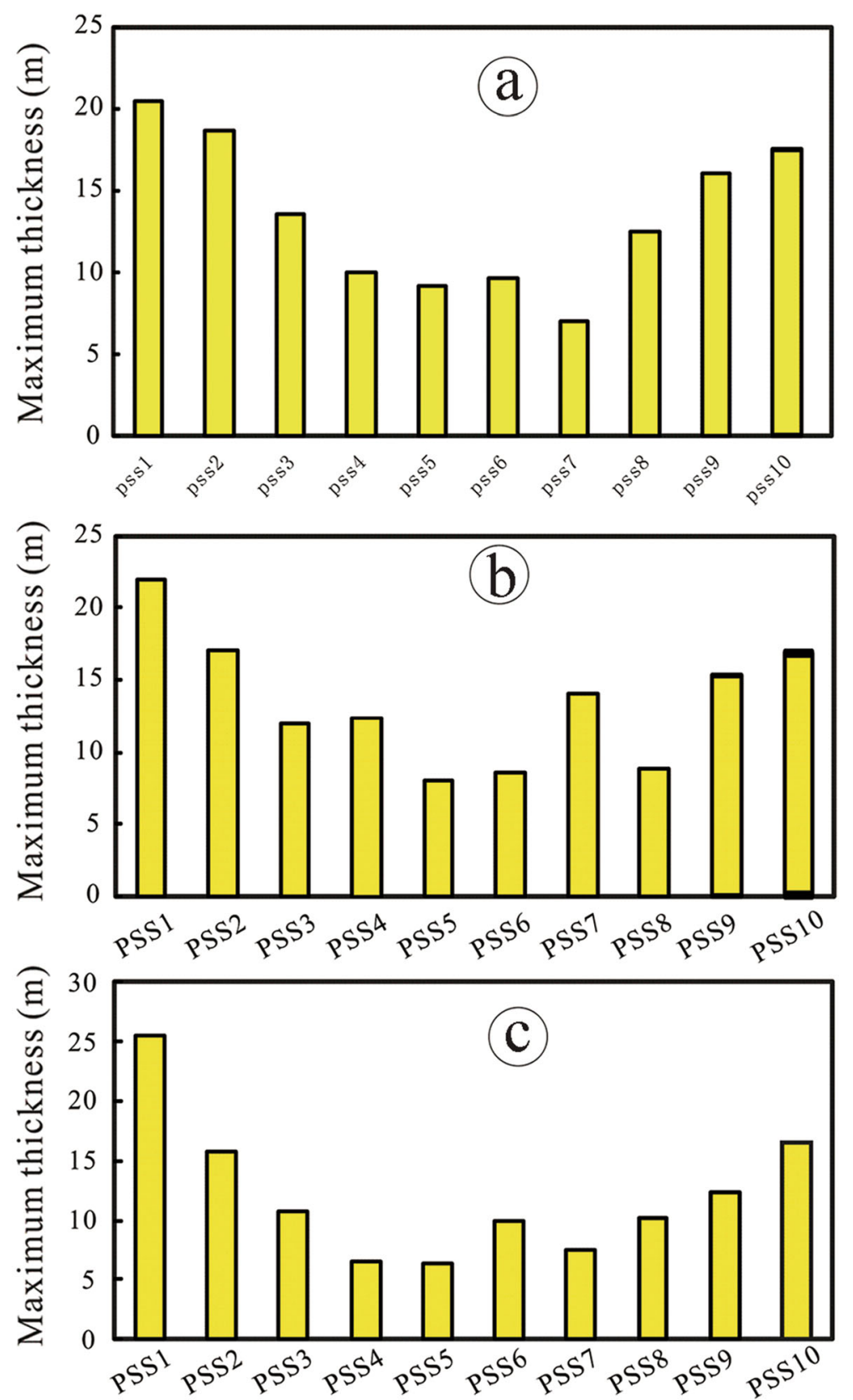

Fig. 11 Distribution of the maximum thickness of sandstones in individual parasequence sets of SQ1 in HHKA. a-BZ26 area, b-BZ34 area, c-BZ29 area

piecing tabular texture with high amplitude, high continuity and wave-sub-parallel reflection configuration.

\subsubsection{Sequence texture controlling the planar association features of sandbodies}

In the depositional phase of the early period of TST, lake level declined and lake area reduced greatly, meandering fluvial delta was characterized by a fan-shape (or lump shape). Channels were wide with width about several hundreds of meters to several kilometers. The thickness of a single-channel sandbody was about 2-10 m. Channel sanbodies were distributed in strip- pod-shape along the water with a relatively better connection (Liu et al. 2016, 2018).

In the depositional phase of late TST-early HST, regressive shallow water delta developed with lake level rising and gradual increase of lake area. Sandbodies are mostly delta front distributary channel deposits, channel narrows down gradually and is easy to shift and form net rivers on a flat surface. The distributary channel is dominated by delta front distributary channel sandbodies which are sheet-like with moderate- to high-degree. The single interval of the 
subaqueous distributary channel sandbodies which are sheet-like with moderate- to high-degree is $0.5-3 \mathrm{~m}$ thick and the thickest reaches $6 \mathrm{~m}$. Single channel sandbody extends to some distances laterally with relatively weak connections among channels (Liu et al. 2016, 2018).

During the late phase of HST, rise of lake level reduced and lake area basically was unchanged. However, the frequency and intensity of lake level fluctuation gradually increased relatively due to the increase of river action. This type of delta deposit is characterized by subaqueous channel sandbody of inner front which is sheet-like with moderate degree and distal sand bar of external front. The weak reconstruction of the lake during the process of subaqueous channel of the external front extending to the relatively deep water area led to very weak sheet-like degree and thus the shape of subaqueous channel sandbody is well preserved. The external island-like sheet sandbody and strip-like distal subaqueous channel sandbody developed at the topset part of some subaqueous channel sandbodies of delta front (Liu et al. 2016, 2018).

\subsection{Palaeogeomorphologic features controlling the lateral inhomogeneity of sandbodies}

4.2.1 Main type features of palaeogeomorphology

The Neogene of the Bohai offshore basin which was a shrinking-phase lacustrine basin, is significantly different from the tectonically active rift lacustrine basins in their palaeogeomorphology. Even compared to the large-scale depressional lacustrine basin with relatively stable tectonics, those plentiful multi-grade slope break belts were not developed here (such as the Jurassic of the Junggar Basin) (Lin et al. 2000; Wang et al. 2004; Liu et al. 2006, 2015). However, a comprehensive investigation combining tectonics and detailed interpretation indicates that the following several types of "micro" palaeogeomorphology develop in the study area in different depositional periods due to the deposition and relatively weak syndepositional rifting.
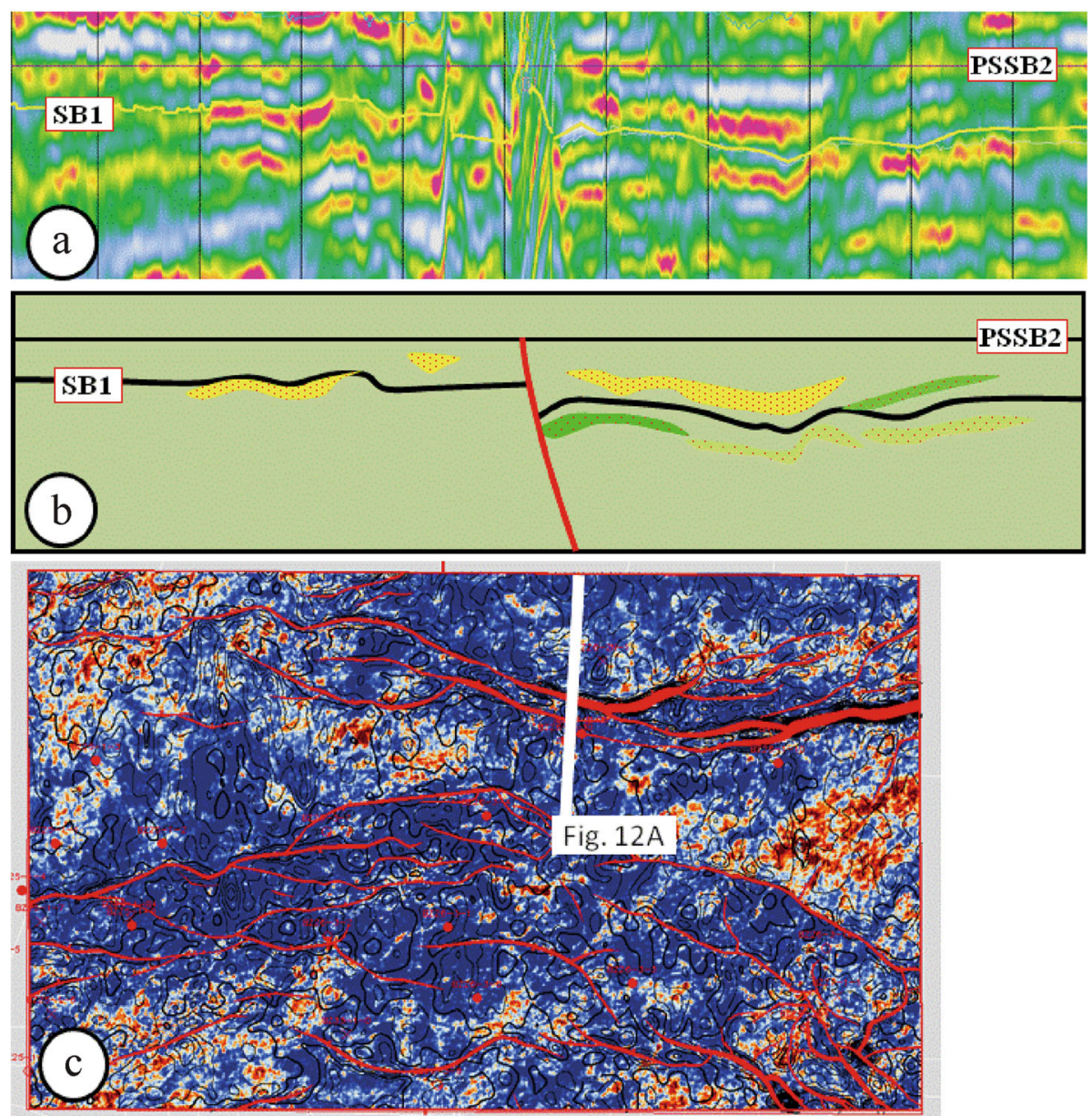

Fig. 12 Syndepositional faults (structural slope break belts) of PSS1 controlling sandbodies in HHKA. Attribute and tectonic interpretation are from 3-D seismic survey of BZ26 area. $\mathbf{a}$ is the seismic profile (seeing location for Fig. 12c); $\mathbf{b}$ is seismic structure and lithologic interpretation above and under the parasequence set boundary. Lithology above and under the boundary is of intense segmentation influenced by the syndepositional fault. $\mathbf{c}$ is the stratal slicing of root mean square amplitude of PSS1 
The first type is tectonic slope break belt. Although the syndepositional fault is not obvious, syndeposition occurs in local strata of some areas (Fig. 12).

The second type includes a variety of microgeomorphology types formed by deposition. When sediments of late phases deposit after the accumulation of early depositional systems, due to the differences of compaction and anti-erosion resulted by the horizontal differences of lithology of early deposits, a variety of relative "highs" and "lows" of micro palaeogeomorphology could occur on a flat surface (Fig. 13) with obvious divisions. The relatively micro palaogeomorphological highs are named as local subaqueous uplifts if they extend to specific range laterally. Similarly, the relatively palaeogeomorphological lows can be divided into some local small sags and channels on a flat surface which belong to the same area with the increasing local accommodation space. A variety of these micro palaeogeomorphological "highs" and "lows" are closely related with the early deposits and their planar distribution.

\subsubsection{Control of palaeogeomorphology on sandbodies}

In shallow water lacustrine basins, the palaeogeomorphology basically changes the accommodation space of sediments deposited at the same depositional period on a flat surface, and furthermore controls the horizontal inhomogeneity of sandbodies.

Usually sandbodies are naturally separated by different accommodation space above and under the tectonic slope break belt formed by syndepositional rifting. The geographic location of the basin where depositional rifts
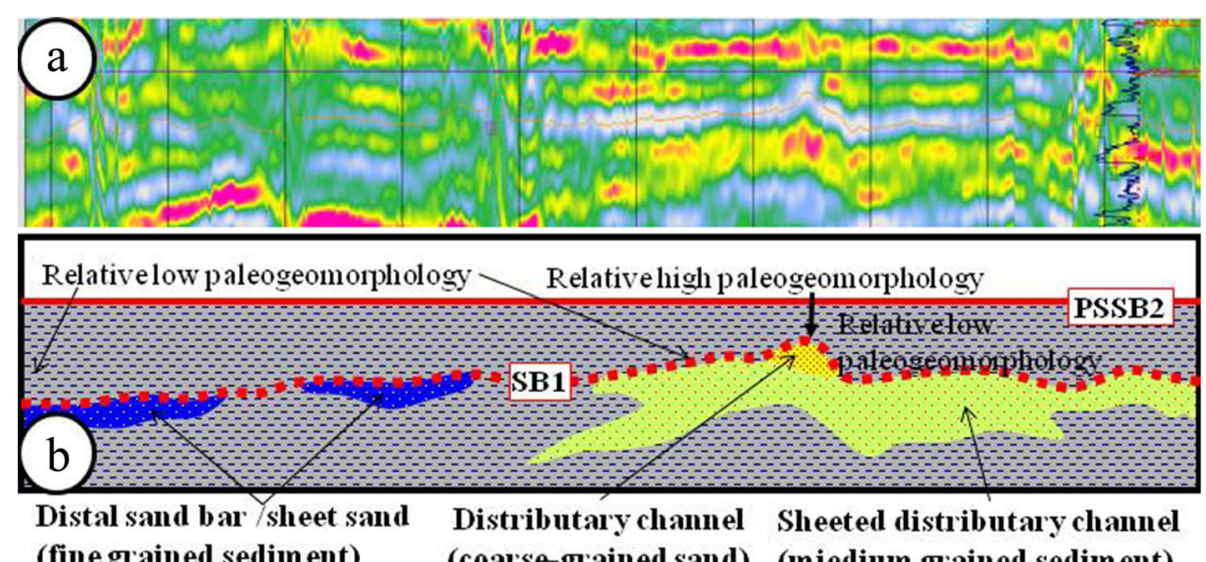

(fine grained sediment) (coarse-grained sand) (miedium grained sediment)

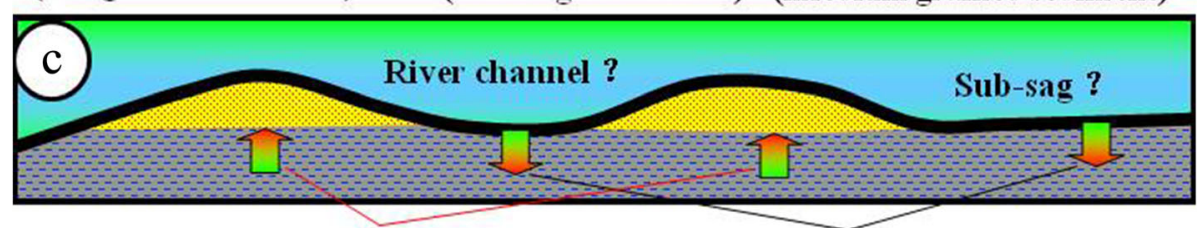

Relative high paleogeomorphology Relative low paleogeomorphology

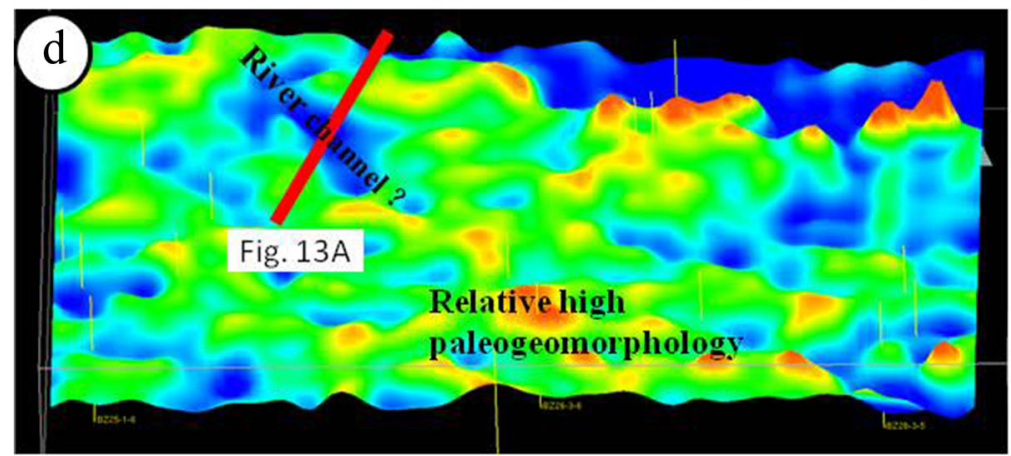

Fig. 13 Sedimentation controls the formation of relative palaeogeomorphology and local sub-sags and channel of later periods (Taking PSS1 of BZ26 area as an example). $\mathbf{a}$ is the seismic profile (Seeing location for Fig. 13d); $\mathbf{b}$ is the seismic lithologic interpretation. Interpretation of lithology under the boundary indicates that areas where sandbodies develop tend to form local palaeo-highs due to their strong anti-erosion ability and are uneasy to be compacted; c shows the channels and small sub-sags formed by relative palaeogeomorphological height difference. Relatively low palaeogeomorphology forms long and narrow shape which represent channels of late periods; $\mathbf{d}$ is a $3-\mathrm{D}$ display of PSS1 palaeogeomorphology in BZ26 area 
develop, the lake level at that phase and other factors should be taken into consideration to investigate how sandbodies are controlled and what types of sandbodies are controlled. Figure 12 indicated that the northern rift slope break belt in BZ26 area obviously controlled the extension of the shallow water delta from northeast towards the south. Location shown in the figure is the external depositional area of the northeast delta which changed into shallow lacustrine facies towards the south. The syndepositional rift obviously separated two sheet sands in the south and north respectively. The sheet sand under the rift slope break belt is obviously thicker and with a larger scale compared to the sand above the slope break belt since it's close to the provenance and with a larger accommodation space. A series of local syndepositional faults developed in BZ34 area as well and their controls on sandbodies and distribution features are approximately similar as those in BZ26 area. In addition, several faults with opposite directions composed "V-shape" valleys combinations which are usually favorable areas for development of various distributary channel sandbodies and front sheet sands.

Relative differences of geomorphology lead to the differential distribution of accommodation space. As for the same depositional phase, sandbody usually develops well in local low areas (Fig. 13). The interpretation of seismic profiles indicated that the geomorphology during the PSS1 depositional phase was unevenly controlled by the sedimentary types in early phases. Amplitude is obviously high above the relatively lower boundary (PSSB1), on the contrary, it was characterized by low amplitude. This is a common characteristic occurring in the shallow intervals of the HHKA.

Different types of distributary channels tend to develop in palaeogeomorphology with channel shape feature. Figure 14 interpreted a distributary channel within PSS6 which was controlled by valley geomorphology in BZ26 area. The distributary channel was a local reflection with high amplitude on seismic profile and developed in relatively low areas (Fig. 14a). It was a seismic reflection event with good horizontal continuity and high amplitude along its developing direction. Under PSSB5, amplitude was low which indicated that early deposits were dominated by argillaceous sediments (Fig. 14b). Argillaceous sediments are easily to be compacted and eroded thus can form paleo-valleys of low topography (Fig. 14c).

In addition, at relatively high lake level phases, in the paleogeomorphologic highs with certain distribution range, sheet sands of medium- high-degree easily form (Fig. 15) due to the reconstruction of lake water in a long period.
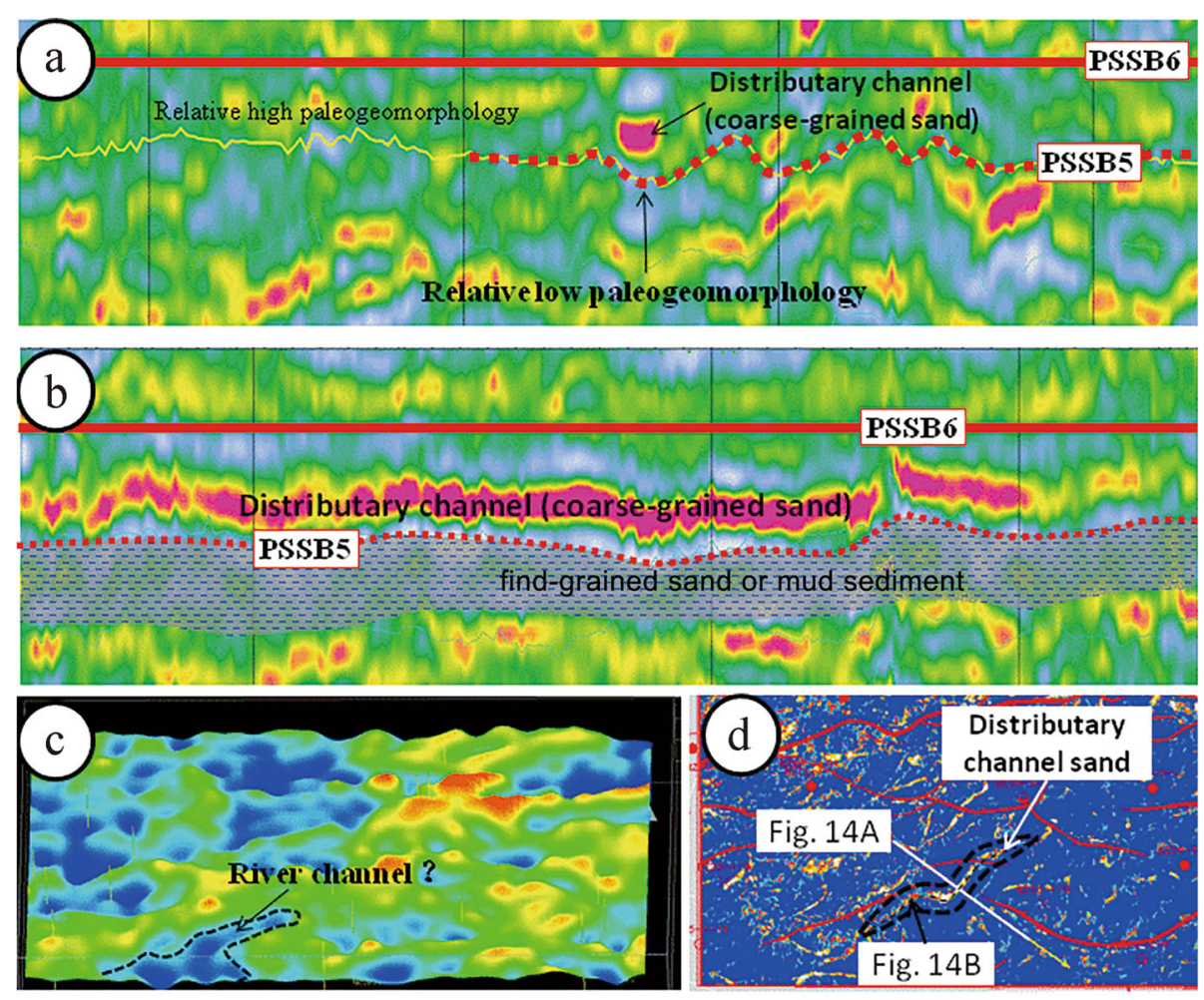

Fig. 14 Control of relatively low paleogeomorphology on sandbodies (Taking PSS5 of BZ26 area as an example). a is the seismic reflection characteristics of distributary channel sandbodies in cross section (Section location is shown is Fig. 14d); b shows the seismic reflection characteristics of distributary channel sandbodies in vertical distribution (Section location is shown in Fig. 14d); c is a 3-D display of PSS5 palaeogeomorphology. Obviously river channel marked in the figure provided good geomorphologic background for the distributary channel sandbodies of Fig. 14d; $\mathbf{d}$ is the stratal slicing of root mean square amplitude of PSS5 


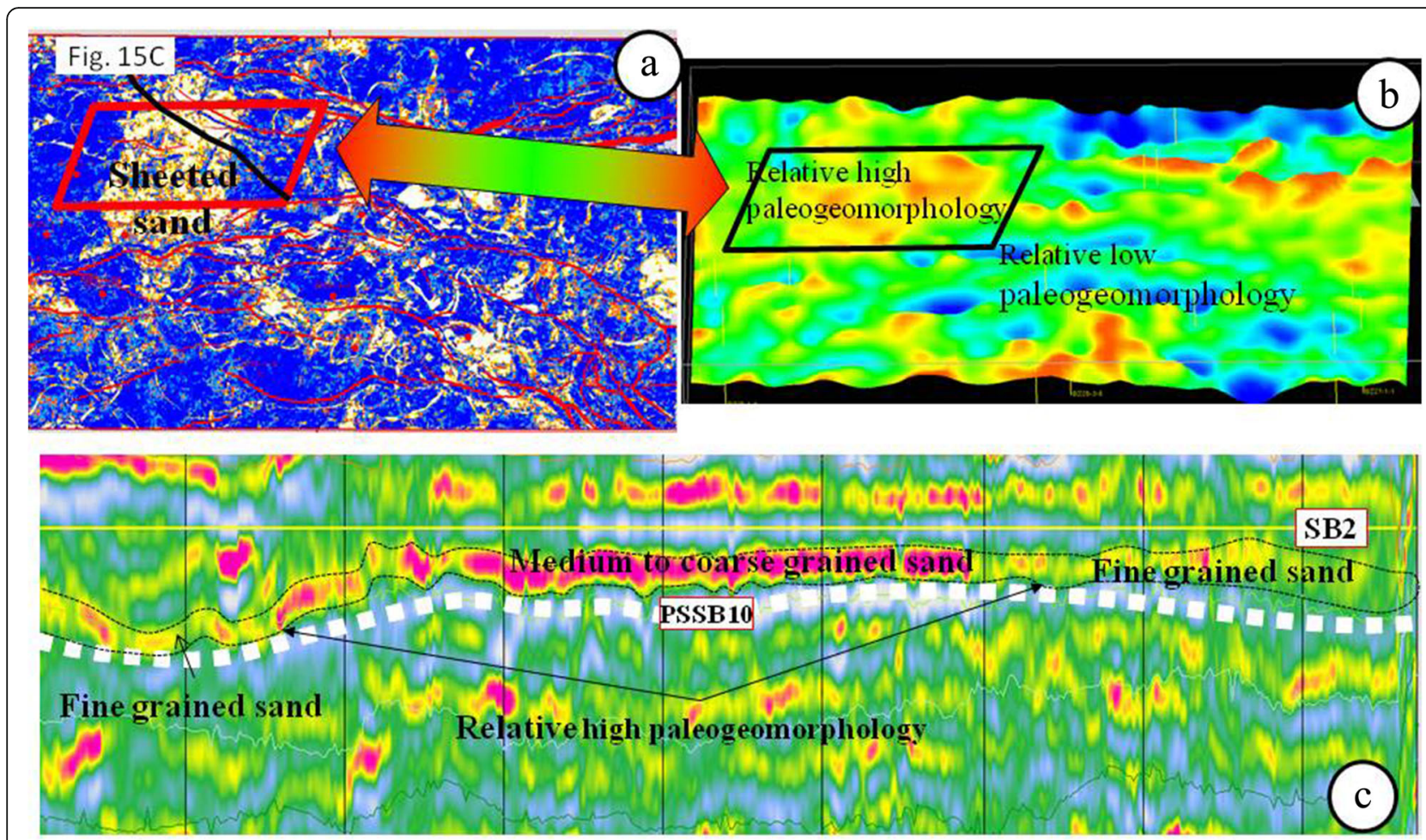

Fig. 15 Sketch shows palaeogeomorphologic highs of a relatively large area controlling sandbodies (Taking PSS10 of BA26 area as an example). a is the stratal slicing of root mean square amplitude of PSS10 in BZ26 area where red color area is sandbody developing area; $\mathbf{b}$ is the palaeogeomorphologic characteristics of PSS10. Red color area represents a local subaqueous uplift in Fig. 15a; $\mathbf{c}$ is the seismic interpretation profile. Lithologic interpretation indicated that lithology of the uplifting area is obviously coarser than the relatively palaeogeomorphologically lower area

\subsection{Base level (lake level) controlling difference of stacking pattern of sandbodies}

Base level and its fluctuation is an important factor in analysis of sequence stratigraphy and sandbody prediction (Wheeler 1964; Jervey 1988; Muto and Steel 2000; Liu et al. 2006; Neal and Abreu 2009). Sea (lake) level in marine (lacustrine) basins is generally considered as base level although it's controversial to some degree. Relative sea (lake) level fluctuation can influence the corresponding variation of accommodation space. Variation of lake level is especially important to lacustrine basins at shrinking period and is characterized by a relatively stable tectonics, large basin area with shallow water and lack of slope break belts.

The paleoclimate cycles of the Paleogene in the HHKA were investigated in details by pre-researchers using sporopollen, algae, color of mudstone, clay minerals etc. (cf. Lai et al. 2009; Liu et al. 2016). The results indicated that climate of the Neogene changed from a warm temperate zone of early phase (the Guantao Formation) to a humid subtropical to warm temperate zone of middle phase (the lower member of the Minghuazhen Formation) and then to a temperate zone of late phase (the upper member of the Minghuazhen Formation)(Liu et al. 2016). The lower member of the Minghuazhen Formation itself experienced two climate cycles from arid to humid. An obvious climate cycle at the top boundary of the third-order sequence SQ1 reflected a complete cycle of base level rise-fall within a third-order sequence.

\subsubsection{Stacking characteristics of sandbodies in base level rising period}

A low accommodation space approximately corresponds to the early phase of TST which is the early phase of base level rise when climate is relatively arid, and lake area reduces to a large scale. Whereas most of the study area is still in very shallow water with a small accommodation space due to the entirely wide and gentle basin topography and provenance drainages accumulate towards the center of the basin. Sandbodies usually contact with each other laterally with a piecing pattern. On a flat surface, shallow water deltas are characterized by fan-shape (or lump-shape) meandering fluvial deltas (Fig. 16) and distributary channel sandbodies dominated.

Incised seismic reflection is difficult to be found at the lower member of the Minghuazhen Formation, HHKA which indicated that channel erosion was not obvious during the early period of TST reflecting a slow falling 


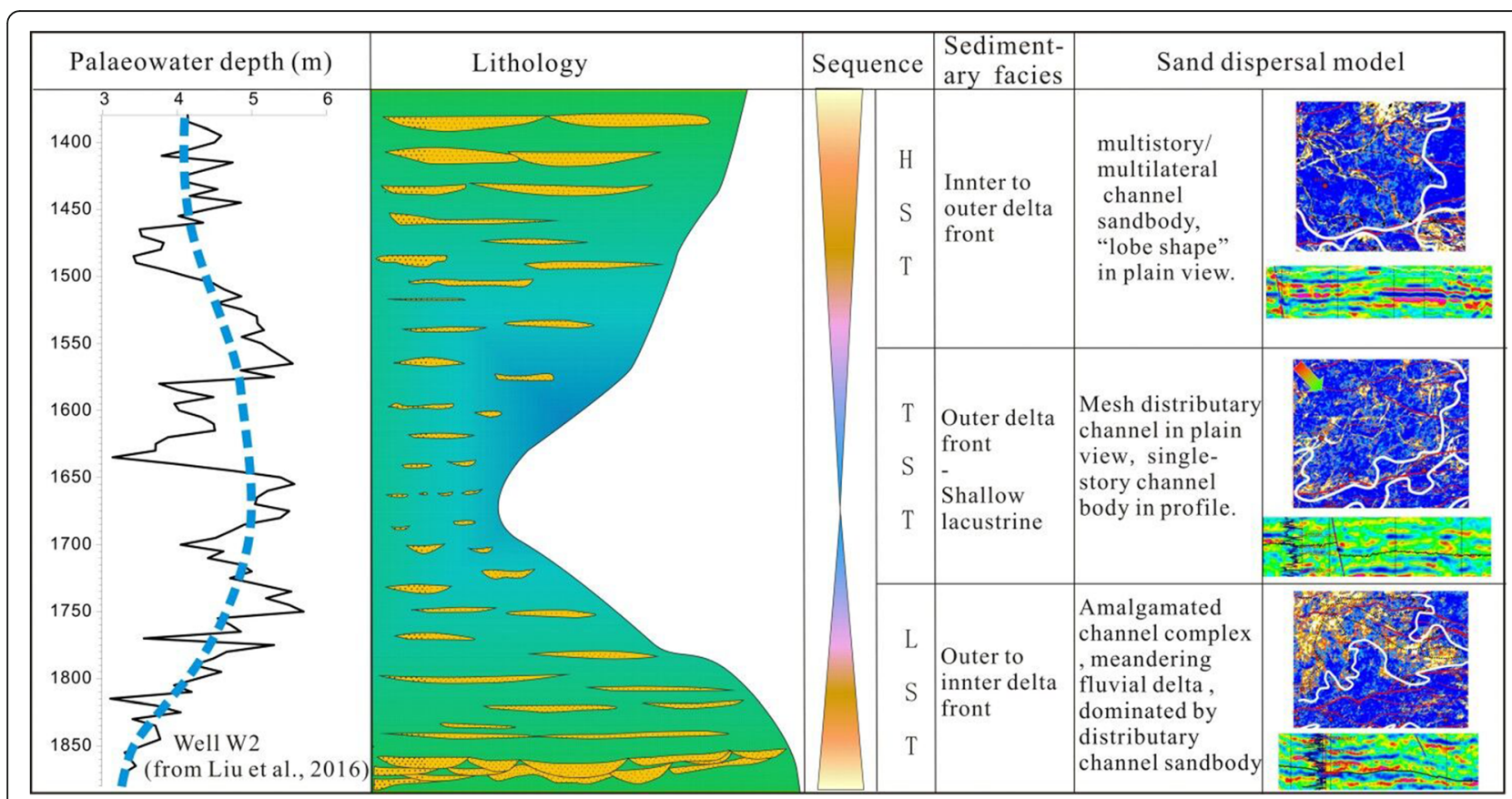

Fig. 16 Analysis of relationship between lake level and sand dispersal system within the high-frequency sequence stratigraphic framework of the Neogene shallow water delta in HHKA. Paleowater depth data are from Liu et al. 2016

process of base level. The flow velocity quickly reduced when the river flew into the lake due to the gentle topography and shallow water of the lacustrine basin. The distributary channel occurred as a non-restrictive river in a fan-shape deposit in the central basin and was frequently reconstructed by lake water forming sheet sands. Meanwhile, sandbodies stacked with each other due to the reconstruction of distributary channels of late phases. Therefore, sandbodies of the early period of TST formed in a setting of gentle topography, slow fall of lake level and a small accommodation space.

The mid- and late-phases base level rising correspond to the late period of TST and the early period of HST respectively. Climate of those periods is relatively humid, lake level rises slowly, the ratio of accomodation space/sediments increases, however water depth of the area is not deep and regressive water delta-net-shape shallow water delta develop (Fig. 16). The distributary channel of inner front of the delta gradually narrows down which tends to shift and forms the net-shape river. During the depositional phase of HST, climate transfers from humid to arid type gradually, lake level extends or does not change, whereas sandbodies are dominated by arrection-weak progradation stacking pattern. Sandbodies are mostly delta front distributary channel deposits, and the channel width increases gradually which is easy to shift. With the increase of the accommodation space, the influence of distributary channel decreases and the decreasing of channel scale can be reflected by drilling well/well logging and seismic profiles.

\subsubsection{Sandbody stacking characteristics during base level slow falling period}

The slow falling phase of base level approximately corresponds to the late phase of HST when arid climate occurs, lake level reduces and lake area shrinks with a moderate accommodation space. Sandbodies of this delta type are different due to the difference of water depth between the internal and external delta front. The flexibility of internal delta front increases, distributary channel sandbodies with a larger width/thickness ratio tend to distribute continuously and form wide spread sheet sands with the increasing width of distributary channel, the decrease of water depth, and suspension load as dominated parts. The form of the sandbodies of subaqueous channels is well preserved due to the very poor sheet degree resulted by the weak reconstruction of lake water when subaqeous channel of external front gradually extends into deep water area (Fig. 16).

\section{Conclusions}

1) Sequence texture clearly influences the vertical development degree of sandbodies and their stacking pattern and controls the planar distribution of sandbodies meanwhile. During the lowstand systems tract phase, channel sandbodies distribute in stripped, podiform shape along water flow direction and sandbodies are closely connected. During the highstand systems tract phase, shape of the subaqueous channel 
sandbodies is well preserved due to the weak reconstruction of lake water.

2) In shallow water lacustrine basins, relative topographic height difference leads to change of distribution of accommodation space, and distributary channels sandbodies usually develop well in local lowlying areas where accommodation space increases.

3) The delta is dominated by distributary channel sandbodies during the early period of base level rising and sandbodies contact with each other in a lateral stacking pattern whereas characterized by a fan shape in plain view. Distributary channels gradually narrow down and tend to shift and change during the midlate-period of base level rising, while sandbodies are characterized by the net shape in plain view. During the period of base level slow falling, the multistory/ multilateral channel sandbodies dominated the inner front of shallow-water delta and the delta sand dispersal distributes as a lobe shape on a flat surface.

\section{Acknowledgements}

We would like to thank the National Science and Technology Major Project (Exploration Technologies for Offshore Subtle Oil/Gas) (project no. 2016ZX05024-003-003) and the Fundamental Research Funds for the Central Universities for support. Thanks are also given to anonymous reviewers whose comments improved the quality of the original paper.

\section{Funding}

This research was supported by the National Science and Technology Major Project (Exploration Technologies for Offshore Subtle Oil/Gas) (project no. 2016ZX05024-003-003) and the Fundamental Research Funds for the Central Universities for support.

\section{Availability of data and materials}

High quality subaqueous data involved in this study are from Tianjin Branch, CNOOC including 3-D seismic, core, drilling well and logging data. 3-D seismic data includes 5 3-D surveys in total about $10,000 \mathrm{~km}^{2}$.

\section{Authors' contributions}

$\mathrm{LH}$ designed and directed the study, and conducted main 3-D seismic interpretation involved in the study and confirmed checking of sedimentary results. TLX involved in designing part of the study, conducted sedimentary analysis (drilling well and well logging data). NCL, DXF, YB and LXD contributed to part of interpretation work. LH and TLX wrote the paper. All authors read and approved the final manuscript.

\section{Competing interests}

The authors declare that they have no competing interests.

\section{Publisher's Note}

Springer Nature remains neutral with regard to jurisdictional claims in published maps and institutional affiliations.

\section{Author details}

'Shenzhen Branch of China National Offshore Oil Corporation, Shenzhen, People's Republic of China. ${ }^{2}$ School of Ocean Sciences, China University of Geosciences (Beijing), Beijing 100083, People's Republic of China. ${ }^{3}$ Exploration \& Exploitation Research Institute, Tianjin Branch of China National Offshore Oil Corporation, Tianjin, People's Republic of China.
Received: 26 December 2018 Accepted: 26 March 2019

Published online: 10 May 2019

\section{References}

Allen, J.P., and C.R. Fielding. 2007. Sequence architecture within a lowaccommodation setting: An example from the Permian of the Galilee and Bowen basins, Queensland, Australia. AAPG Bulletin 91: 1503-1539.

Alonso-Zarza, A. M., Z. Zhao, C. H. Song, J. J. Li, J. Zhang, A.Martín-Pérez, R. Martín-García, X. X. Wang, , Y. Zhang, , and M. H. Zhang, 2011. Mudflat/ distal fan and shallow lake sedimentation (upper Vallesian-Turolian) in theTianshui Basin, Central China: Evidence against the late Miocene eolian loess. Sedimentary Geology 222: 42-52.

Brendan, J., O. Reilly, , H. X. Ge, , and L. G. Karl. 2000. Fault geometry and kinematics in the Peng Lai 19-3 field, Bohai Bay, the People's Republic of China. AAPG Bulletin 84: 1472.

Coleman, J.M. 1988. Dynamic changes and processes in the Mississippi River delta. GSA Bulletin 100 (7): 999-1015.

Dai, L., J. Li, X. Zhou, Z. Cui, , and J. Cheng. 2007. Depositional system of the Neogene shallow water delta in Bohai Sea area. Lithologic Reservoirs 19(4): 75-81. (in Chinese with English abstract).

Darmadi, Y., B.J. Willis, and S.L. Dorobek. 2007. Three-dimensional seismic architecture of fluvial sequences on the low-gradient sunda shelf offshore Indonesia. Journal of Sedimentary Research 77: 225-238.

Donaldon, A.C. 1974. Pennsylvanian sedimentation of central Appalalachians. Special Paper of Geological Society of America 148: 47-78.

Feng, Y., S. Jiang, S. Hu, S. Li, C. Lin, and X. Xie. 2016. Sequence stratigraphy and importance of syndepositional structural slope-break for architecture of Paleogene syn-rift lacustrine strata, Bohai Bay Basin, E. China. Marine and Petroleum Geology 69: 183-204.

Fisher, J.A., G.J. Nichols, and D.A. Waltham. 2007. Unconfined flow deposits in distal sectors of fluvial distributary systems: Examples from the Miocene Luna and Huesca systems, northern Spain. Sedimentary Geology 195: 55-73.

Fisk, H. N. 1961. Bar-finger sands of the Mississippi delta. In: A. P. James, et al. (Eds.), Geometry of sandstone bodies, SP22. Electronic Index of AAPG Special Publications, pp. 29-52.

Ganil, M.R., and J.P. Bhattacharya. 2007. Basic building blocks and process variability of a cretaceous delta: Internal facies architecture reveals a more dynamic interaction of river, wave, and tidal processes than is indicated by external shape. Journal of Sedimentary Research 77 (4): 284-302.

Ghinassi, M., Y. Libsekal, M. Papini, and L. Rook. 2009. Palaeoenvironments of the Buia Homo site: High-resolution facies analysis and non-marine sequence stratigraphy in the Alat formation (Pleistocene Dandiero Basin, Danakil depression, Eritrea). Palaeogeography, Palaeoclimatology, Palaeoecology 280: 415-431.

Gilbert, G.K. 1885. The topographic features of Lake shores. Geological Survey Annual Report 5: 75-123.

Glider, S.A., P.H. Leloup, and V. Courtillot. 1999. Tectonic evolution of Tancheng-Lujiang (tan-Lu) fault via middle Triassic to early Cenozoic paleomagnetic. Journal of Geophysical Research 104 (B7): 15365-15390.

Gong, Z., G. Wang, and Q. He. 2000. The Neogene: A main realm of hydrocarbon exploration in Bozhong sag and its surrounding areas. China Offshore Oil Gas (Geology) 14 (3): 145-156 (in Chinese with English abstract).

Hampson, G.J., T. Elliott, and S.J. Davies. 1997. The application of sequence stratigraphy to upper carboniferous fluvio-deltaic strata of the onshore UK and Ireland: Implications for the southern North Sea. Journal of Geological Society, London 154: 719-733.

Han, X.D., Z.H. Lou, Y.M. Yao, W.D. Yang, and X.Y. Cai. 2000. Analysis of the sedimentary dynamic process of the shallow-water Lake Delta in the Songliao Basin, Northeast China. Acta Mineralogica Sinica 20: 305-313 (in Chinese with English abstract)

Hoy, R.G., and K.D. Ridgway. 2003. Sedimentology and sequence stratigraphy of fan-delta and river-delta deposystems, Pennsylvanian Minturn formation, Colorado. AAPG Bulletin 87 (7): 1169-1191.

Hsiao, L.Y., S.A. Graham, and N. Tilander. 2010. Stratigraphy and sedimentation in a rift basin modified by synchronous strike-slip deformation: Southern Xialiao basin, Bohai, offshore China. Basin Research 22: 61-78. 
Jervey, M.T. 1988. Quantitative geological modeling of siliciclastic rock sequences and their seismic expression. In: Wilgus, C.K., Hastings, B.S., Kendall, C.G. St. C, Posamentier, H.W., Ross,C.A., Van Wagoner, J.C. (Eds.). Sea-level Changes: An integrated approach. Society of Economic Paleontologists and Mineralogists (SEPM), Special Publication 42: 47-69.

Keumsuk, L., G.A. McMechan, M. Ro, J.P. Gani, X.X. Zeng Bhattacharya, and C. D. Howell. 2007. 3-D architecture and sequence stratigraphic evolution of a forced regressive top-truncated mixed-influenced delta, cretaceous Wall Creek sandstone, Wyoming, U.S.A. Journal of Sedimentary Research 77 (4): 284-302.

Lai, W., J. Cheng, X. Zhou, J. Li, L. Dai, and Y. Zhang. 2009. Stratigraphic sequence division and sandbody characteristics of peneplain deposits during lacustrine basin shrinking: A case study of lower member of Neogene Minghuazhen formation in the area of Yellow River mouth China Offshore Oil and Gas 21 (3): 157-161 (in Chinese with English abstract).

Lemons, D.R., and M.A. Chan. 1999. Facies architecture and sequence stratigraphy of fine-grained lacustrine deltas along the eastern margin of late Pleistocene Lake Bonneville, northern Utah and southern Idaho. AAPG Bulletin 83: 635-665.

Li, J., H. Liu, C. Niu, and R. Guo. 2014. Evolution regularity of the Neogene shallow water delta in the Laibei area, Bohai Bay Basin, northern China. Journal of Palaeogeography 3 (3): 257-269.

Lin, C.S., Y.L. Pan, J.X. Xiao, F.X. Kong, J.Y. Liu, and H.R. Zheng. 2000. Structural slope-break zone: Key concept for stratigraphic sequence analysis and petroleum forecasting in fault subsidence basin. Earth Science (Journal of China University of Geosciences) 25: 260-265 (in Chinese with English abstract).

Liu, H. 2014. Establishing the sequence-stratigraphic framework of a lacustrine basin during its withering period using multiple methods and technologies: A case study of the Neocene of the Huanghekou sag, Bohai Bay Basin, China. Disaster Advances 7 (7): 52-66.

Liu, H., J. Meng, , and S. Banerjee. 2017. Estimation of palaeo-slope and sediment volume of a lacustrine rift basin: A semi-quantitative study on the southern steep slope of the Shijiutuo uplift, Bohai Offshore Basin, China. Journal of Asian Earth Sciences 147: 148-163.

Liu, H., Y.M. Wang, R.C. Xin, and Y. Wang. 2006. Study on the slope break belts in the Jurassic down-warped lacustrine basin in western-margin area, Junggar Basin, northwestern China. Marine Petroleum Geology 23: 913-930.

Liu, H., Q.L. Xia, I.D. Somerville, Y. Wang, X.H. Zhou, C.M. Niu, X.F. Du, and X. T. Zhang. 2015. Palaeogene of the Huanghekou sag in the Bohai Bay basin, NE China: Deposition-erosion response to a slope break system of rift lacustrine basins. Geological Journal 50: 71-92.

Liu, H., Q.L. Xia, and X.H. Zhou. 2018. Geologic-seismic models, prediction of shallow-water lacustrine delta sandbody and hydrocarbon potential in the Late Miocene, Huanghekou sag, Bohai Bay basin, northern China. Journal of Palaeogeography 7(1): 66-87.

Liu, H., C.C. Zhao, Y.T. Ju, and X.H. Zhou. 2016. Evolution of lacustrine basin in relation to variation in palaeowater depth and delta development: Neogene Bohai Bay basin, Huanghekou area, northern China. Arabian Journal of Geosciences 9: 672.

Liu, L.H., R.K. Zhu, P. Luo, C.M. Zhou, X.Y. Zhang, and W.L. Zhai. 2009. Characteristics and depositional models for the shallow-water deltas of the 5th-6th interval, Xujiahe formation, upper Triassic in Central Sichuan Basin, China. Geoscience 23: 667-675 (in Chinese with English abstract).

Lü, X.G., C.S. Li, X.Y. Cai, B.H. Li, and H.Q. Zhao. 1999. Depositional characteristics and front facies reservoir framework model in SongLiao shallow lacustrine delta. Acta Sedimentologica Sinica 17: 572-577 (in Chinese with English abstract).

Muto, T., and R.J. Steel. 2000. The accommodation concept in sequence stratigraphy: Some dimensional problems and possible redefinition. Sedimentary Geology 130: 1-10.

Neal, J., and V. Abreu. 2009. Sequence stratigraphy hierarchy and the accommodation succession method. Geology 37: 779-782.

Nichols, G.J. 2005. Sedimentary evolution of the lower Clair group, Devonian, west of Shetland: Climate and sediment supply controls on fluvial, aeolian and lacustrine deposition. In: A.G. Doré and B.A. Vining
(Eds.). Petroleum geology: North West Europe and Global Perspectives Proceedings of the $6^{\text {th }}$ Petroleum Geology Conference, 957-967. London: Geological Society.

Nichols, G.J., and J.A. Fisher. 2007. Processes, facies and architecture of fluvial distributary system deposits. Sedimentary Geology 195: 75-90.

North, C.P., and S.K. Davidson. 2012. Unconfined alluvial flow processes: Recognition and interpretation of their deposits, and the significance for palaeogeographic reconstruction. Earth-Science Reviews 111: 199-223.

Plint, A.G. 2000. Sequence stratigraphy and paleogeography of a Cenomanian deltaic complex: The Dunvegan and lower Kaskapau formations in subsurface and outcrop, Alberta and British Columbia, Canada. Bulletin of Canadian Petroleum Geology 48 (1): 43-79.

Plint, A.G., P.J. Mccarthy, and U.F. Faccini. 2001. Nonmarine sequence stratigraphy: Updip expression of sequence boundaries and systems tracts in a high-resolution framework, Cenomanian Dunvegan formation, Alberta foreland basin, Canada. AAPG Bulletin 85: 1967-2001.

Postma, G. 1990. An analysis of the variation in delta architecture. Terra Nova 2 (2): 124-130.

Qi, J.F., R.J. Deng, X.H. Zhou, and K.X. Zhang. 2008. Structural characteristics of the Tanlu fault zone in Cenozoic basins of offshore Bohai. Science in China (Series D) 38 (suppl): 19-29.

Schellart, W.P., and G.S. Lister. 2005. The role of east Asian active margin in widespread and strike-slip deformation in East Asia. Journal of Geological Society 162: 959-972.

Tian, L., H. Yu, X. Zhou, W. Peng, and Y. Wang. 2009. Major control factors of petroleum accumulation in Huanghekou sag. Xinjiang Petroleum Geology 30 (3): 319-321 (in Chinese with English abstract).

Vail, P.R., F. Audemard, S.A. Bowman, et al. 1991. The stratigraphic signatures of tectonics, eustasy and sedimentology: An overview. In Cycles and events in stratigraphy, 617-659. Berlin: Springer-Verlag.

Vail, P.R., R.M. Mitchum, S.Thompson. 1977. Seismic stratigraphy and global changes of sea level. In: Payton, C.E. (Ed.), Seismic stratigraphy and applications to hydrocarbon exploration, AAPG Memoir 26: 83-97.

Van Wagoner, J.C, HW Posamentier, R.M. Mitchum, PR Vail, JF Sarg, TS Loutit, J. Hardenbol, 1988. An overview of sequence stratigraphy and key definitions. In: Wilgus, C.K., Hastings, B.S., Kendall, C. G. St. C, Posamentier, H.W., Ross, C.A., Van Wagoner, J.C. (Eds.), Sea-level Changes: An integrated approach, Society of Economic Paleontologists and Mineralogists (SEPM) Special Publication 42: 39-45.

Wang, Y.M., H. Liu, R.C. Xin, W.D. Jin, Y. Wang, and W.G. Li. 2004. Lacustrine basin slope break-a new domain of strata and lithological trap exploration. Petroleum Science 1: 55-61.

Wheeler, H.E. 1964. Base level, lithostratigraphic surface and time stratigraphy. GSA Bulletin 75: 599-610.

Xu, C., P. Jiang, F. Wu, B. Yang, and D. Li. 2002. Discovery and sedimentary characteristics of the Neogene delta in Bozhong depression and its significance for oil and gas exploration. Acta Sedimentologica Sinica 20 (4): 588-593 (in Chinese with English abstract).

Zhang, C.M., T.J. Yin, YJ. Zhu, and L.M. Ke. 2010. Shallow-water deltas and models. Acta Sedimentologica Sinica 28: 933-944 (in Chinese with English abstract).

Zhou, X.H., Y.X. Yu, L.J. Tang, D.Y. LV, and Y.B. Wang. 2010. Cenozoic offshore basin architecture and division of structural elements in Bohai Sea. China Offshore Oil and Gas 22 (5): 285-289 (in Chinese with English abstract).

Zhu, W., J. Li, X. Zhou, and Y. Guo. 2008. Neogene shallow water deltaic system and large hydrocarbon accumulations in Bohai Bay, China. Acta Sedimentologica Sinica 26 (4): 575-582 (in Chinese with English abstract).

Zhu, X.M., H.L. Zeng, S.L. Li, Y.L. Dong, S.F. Zhu, D.N. Zhao, and W. Huang. 2017. Sedimentary characteristics and seismic geomorphologic responses of a shallow-water delta in the Qingshankou formation from the Songliao Basin, China. Marine and Petroleum Geology 79: 131-148.

Zou, C.N., X.Y. Zhang, P. Luo, L. Wang, Z. Luo, and L.H. Liu. 2010. Shallowlacustrine sand-rich deltaic depositional cycles and sequence stratigraphy of the upper TriassicYanchang formation, Ordos Basin, China. Basin Research 22: 108-125. 